\title{
Guidelines
}

\section{Guidelines for the welfare and use of animals in cancer research}

\author{
P Workman*, , EO Aboagye ${ }^{2}$, F Balkwill ${ }^{3}$, A Balmain ${ }^{4}$, G Bruder $^{5}$, DJ Chaplin 6 , JA Double B J Everitt $^{8}$, \\ DAH Farningham ${ }^{9,18}$, MJ Glennie ${ }^{10}$, LR Kelland ' , V Robinson ${ }^{12}$, IJ Stratford ${ }^{13}$, GM Tozer ${ }^{14}, \mathrm{~S} \mathrm{Watson}^{15}$, \\ SR Wedge ${ }^{16}$, SA Eccles ${ }^{*, 1}$, An ad hoc committee of the National Cancer Research Institute ${ }^{19}$, \\ Observers: V Navaratnam ${ }^{17}$ and S Ryder ${ }^{17}$
}

'Cancer Research UK Centre for Cancer Therapeutics, The Institute of Cancer Research, Cotswold Road, Sutton, Surrey SM2 5NG, UK; ${ }^{2}$ Comprehensive Cancer Imaging Centre, Imperial College London Faculty of Medicine, Hammersmith Hospital Campus, Du Cane Road, London WI 2 ONN, UK; ${ }^{3}$ Centre for Cancer \& Inflammation, Barts and The London School of Medicine and Dentistry, John Vane Science Centre, Charterhouse Square, London ECIM 6BQ, UK; ${ }^{4}$ Helen Diller Family Comprehensive Cancer Center, University of California San Francisco 1450 3rd Street, San Francisco, CA 94 I58, USA; ${ }^{5}$ Paterson Institute for Cancer Research, University of Manchester, Wilmslow Road, Manchester M20 4BX, UK; ${ }^{6}$ OXiGENE Inc., 701 Gateway Boulevard, San Francisco, CA 94080, USA; ${ }^{7}$ University of Bradford, Richmond Road, Bradford BD7 IDP, UK; ${ }^{8}$ GlaxoSmithkline Pharmaceutical R\&D, PO Box 13398, Five Moore Drive, N2.22 10.2B, Research Triangle Park, NC 27709-3398, USA; ${ }^{9}$ Cancer Research UK, Clare Hall Laboratories, Blanche Lane, South Mimms, Herts EN6 3LD, UK; ${ }^{10}$ Tenovus Laboratory, Cancer Sciences Division, Southampton University School of Medicine, General Hospital, Southampton SO 6 6YD, UK; " Cancer Research Technology Development Laboratories, Wolfson Institute for Biomedical Research, University College London, Gower Street, London WCIE 6BT, UK; ${ }^{12}$ National Centre for the Replacement, Refinement and Reduction of Animals in Research 20, Park Crescent, London WIB IAL, UK; ${ }^{13}$ School of Pharmacy and Pharmaceutical Sciences, University of Manchester, Stopford Building, Oxford Road, Manchester MI 3 9PT, UK; ${ }^{14}$ Department of Oncology, K Floor, School of Medicine, University of Sheffield, Beech Hill Road, Sheffield SIO 2RX, UK; ${ }^{15}$ Division of Pre-Clinical Oncology \& PRECOS, D Floor West Block, Queen's Medical Centre, University Hospital, Nottingham NG7 2UH, UK; ${ }^{16}$ Cancer Bioscience, AstraZeneca, Mereside, Alderley Park, Macclesfield, Cheshire SKIO 4TG, UK; ${ }^{17}$ The Home Office, ASPD (mail point IB), I st floor Seacole Building, 2 Marsham Street, London WIP 4DF, UK; ${ }^{18}$ Current address: Medical Research Council, 20 Park Crescent London WIB IAL, UK

British Journal of Cancer (2010) 102, I555-1577. doi: 10.1038/s.bjc.6605642 www.bjcancer.com (c) 2010 Cancer Research UK

Keywords: animal welfare; cancer research; fundamental and translational research; replacement, reduction and refinement (3Rs); pilot studies; tumour models; genetically engineered mouse models; human tumour xenografts; orthotopic models; metastatic models; therapy; imaging; pharmocokinetic, pharmacodynamic and efficacy studies; drugs; radiation therapy; imaging techniques; anaesthesia; restraint; humane endpoints; tumour burden; clinical signs; publication; best practice

\begin{abstract}
Animal experiments remain essential to understand the fundamental mechanisms underpinning malignancy and to discover improved methods to prevent, diagnose and treat cancer. Excellent standards of animal care are fully consistent with the conduct of high quality cancer research. Here we provide updated guidelines on the welfare and use of animals in cancer research. All experiments should incorporate the 3Rs: replacement, reduction and refinement. Focusing on animal welfare, we present recommendations on all aspects of cancer research, including: study design, statistics and pilot studies; choice of tumour models (e.g., genetically engineered, orthotopic and metastatic); therapy (including drugs and radiation); imaging (covering techniques, anaesthesia and restraint); humane endpoints (including tumour burden and site); and publication of best practice.
\end{abstract}

\footnotetext{
*Correspondence: Professor P Workman and Dr SA Eccles;

E-mail: Paul.Workman@icr.ac.uk and Sue.Eccles@icr.ac.uk

We dedicate these Guidelines to Professor Lloyd Kelland and Dr Peter Twentyman, who made important contributions to these Guidelines and/ or previous published versions, and who have now sadly passed away.

${ }^{19}$ The National Cancer Research Institute (NCRI) is a partnership of 21 organisations from the government, charity and commercial sectors who support cancer research in the UK. Further information about NCRI can be found at http://www.ncri.org.uk
}

Received 5 March 2010; accepted 15 March 2010

\section{LAY SUMMARY}

In order for scientists to understand how cancers develop and spread throughout the body and to discover new and more effective ways to diagnose and treat cancer, it is necessary to carry out research on live animals. Animal studies (over $95 \%$ of which are conducted in mice) are essential to understand the complexities of the fundamental processes that underpin cancer within living organisms. They are also required by regulatory authorities before any trials of new drugs can be tested in humans. Animal studies are only performed after every feasible test has been conducted on cancer cells in the laboratory and where no alternative exists. Adverse effects on the animals are minimised as far as possible. However, it is a source of concern for society and research scientists alike that, as we cannot replace all animal experiments in the immediate future, the highest standards of welfare are upheld. This publication builds on two previous sets of guidelines to provide updated and enhanced recommendations for the care and use of animals in cancer research; to develop procedures that reduce, replace or refine animal studies; and to communicate best practice throughout the world. In all cases, however, experimental designs and procedures should be tailored to the needs of the specific studies. 


\section{BACKGROUND AND SCOPE}

Over the last decade there has been an extraordinary increase in our knowledge of the fundamental molecular processes that are involved in the development of cancer and its response to treatment (Hanahan and Weinberg, 2000; Vogelstein and Kinzler, 2004; Stratton et al, 2009). The public rightfully expect this explosion in basic research understanding to be translated into rapid improvements in prevention, diagnosis and treatment, particularly for the more common cancers and indeed for any malignant disease where there is still clearly an unmet need for more effective therapies. In recent years the identification of the genes and pathways that give rise to cancer dependencies and vulnerabilities has taken us further towards the development of individualised, molecularly targeted therapies (Sawyers, 2004; Collins and Workman, 2006; Workman and de Bono, 2008).

Along with growth in fundamental knowledge and greater translational insight has come the development of new in vitro and ex vivo methodologies and research techniques that should further extend our still incomplete genetic, molecular and holistic understanding of cancer, and in addition should help to ensure that improved methods for diagnosis, therapy and prevention will be developed more effectively for patient benefit. Nevertheless, we are still some way from the point where all of the necessary information that is required to introduce a new drug into the clinic in terms of safety and efficacy could be gained without the use of animals in research. Moreover, animals remain essential to extend our understanding of the mechanisms responsible for cancer and to identify, for example, new targets and biomarkers.

It is clearly important that the welfare of animals in cancer research is protected, both from an ethical point of view and also because it is widely acknowledged to be entirely consistent with good science (Osborne et al, 2009). Under the earlier sponsorship of the former United Kingdom Coordinating Committee for Cancer Research (UKCCCR), two sets of guidelines have been published previously (Workman, 1988; Workman et al, 1998). Although these guidelines were well received, and are still widely used and cited, it is over 10 years since they were last revised, in which time the science has moved on appreciably. The main aim of this article is to provide new guidelines for the cancer research community concerning the use of experimental animals in oncology, with a major emphasis on their welfare. We focus on rodents as these are predominantly used for cancer research: in 2008, for example, the UK government Home Office statistics showed that $96.8 \%$ of animals used in cancer research were mice (http://scienceandresearch.homeoffice.gov.uk/ animal-research/publications-and-reference/statistics/index.html). While development of medicines may require testing in other species, use of animals in regulatory toxicology is outside the scope of this review.

The present guidelines should be applied to studies focused on all aspects of cancer research, including experiments aimed at understanding fundamental cancer biology as well more translational work, and should be used in conjunction with more general guidelines for the care and welfare of animals (see examples below and Additional information). It is expected that animal housing will be maintained according to the highest standards, including environmental enrichment (Tsai et al, 2006), and that local ethical review will precede any experimental animal studies. In addition, these guidelines should be used in conjunction with appropriate national legislation: UK Animals (Scientific Procedures) Act 1986; USA Institute for Laboratory Animal Research (ILAR) Guide for the Care and Use of Laboratory Animals (http://dels.nas.edu/Laboratory); EU webpage on laboratory animals (http://ec.europa.eu/environment/ chemicals/lab_animals/home_en.htm); Public Health Service Policy on Humane Care and Use of Laboratory Animals (Office of Laboratory Animal Welfare, National Institutes of Health,
2002); http:/grants.nih.gov/grants/olaw/references/phspol.htm. A complementary key recent publication, coordinated by the UK's National Centre for the Replacement, Refinement and Reduction of Animals in Research (NC3R), is also recommended (Biotechnology and Biological Sciences Research Council; Department for Environment, Food and Rural Affairs; Medical Research Council; Natural Centre for the Replacement, Refinement and Reduction of Animals in Research; Natural Environment Research Council; Wellcome Trust, 2008). We also feel it is important that the public is made fully aware of the current justification for the use of animals in cancer research and the genuine concern for their welfare by researchers involved with their use. To help with this, a lay summary of the guidelines is also provided on page 1555 . A glossary of terms can be found at the end of this article. Finally, it is important to emphasise that high standards of animal care and welfare should be fully consistent with, and helpful to, the conduct of high-quality cancer research (Osborne et al, 2009).

\section{GENERAL RECOMMENDATIONS}

The use of animals raises scientific and ethical challenges. In 1959, Russell and Burch published The Principles of Humane Experimental Technique in which they stated that all animal experiments should incorporate, as far as possible, the 3Rs: replacement (of animals with alternative methods), reduction (in the numbers of animals used to achieve scientific objectives) and refinement (of methods to minimise animal suffering) (Russell and Burch, 1959). These principles underpin the legislation, guidelines and working practices concerning the use of animals in scientific procedures. Consideration of the $3 \mathrm{Rs}$ must be an integral part of planning cancer research using animals and the 3 Rs need to be implemented throughout the lifetime of the study. Funding bodies and scientific journals (Osborne et al, 2009) should encourage scientists to use humane methods, to supply information on how the principles of the $3 \mathrm{Rs}$ are implemented and to publish improvements in experimental design and animal models for the benefit of the research community (www.nc3rs.org.uk/reportingguidelines). Details on the application of the 3Rs in cancer research are provided in Box 1 for ease of reference, together with information on implementation and monitoring in Box 2. Examples of tumour models, experimental design and procedures are provided throughout these guidelines. However, it is emphasised that these are intended to act as a guide only, and each study should be tailored to the specific experimental objectives.

\section{TUMOUR MODELS}

Preclinical cancer studies fall into two broad categories: those using tumour cell transplantation (Tables $1 \mathrm{~A}$ and $\mathrm{B}$ ), and those in which tumours arise or are induced in the host (Tables $2 \mathrm{~A}$ and $\mathrm{B}$ ). The choice of animal model depends on the scientific question being investigated, but the mildest possible procedure should always be used. An example of the type of illustrative aid that can be used to facilitate the rational choice of appropriate models is shown in Figure 1. Cellular interactions and immune responses require immunocompetent animals and syngeneic systems, whereas cancer development or chemoprevention studies may use transgenic models or chemically induced tumours. In the case of translational studies designed, for example, to discover and develop therapies to exploit oncogenic abnormalities, the tumours should have the appropriate molecular genetic defect. Furthermore, real-time optical imaging will require engineered bioluminescent/fluorescent tumour models.

\section{Transplantation tumour models}

These normally involve the transplantation of mouse or rat tumour cells into a host of the same (syngeneic) species and strain. Growth 


\section{Box I THE 3Rs: \\ Replacement, Reduction AND Refinement}

\section{Replacement}

Absolute replacement techniques avoid the use of animals; relative replacement techniques include substituting non-vertebrate species

I. Investigate the potential of novel and existing alternative approaches to animals

2. Use in silico and/or in vitro pre-screens before commencing animal studies

\section{Reduction}

Minimise the number of animals used to achieve specific scientific objectives

I. Ensure that all studies are scientifically robust and apply appropriate statistical methods to experimental design

2. Reduce experimental variability by conducting studies of animals of defined health status and, wherever possible, using inbred strains

3. Minimise surplus breeding by avoiding unnecessarily narrow specifications for animal sex, age and weight

4. Freeze rodent embryos, sperm and cancer cell lines not immediately required for scientific studies

5. Prevent duplication by making specific strains and genetically modified lines available throughout the research community

6. Consider use of serial sampling or longitudinal imaging in which each animal acts as its own control to reduce study group sizes

\section{Refinement}

Continual review of improvements in experimental design, techniques and husbandry to minimise adverse effects and improve welfare

I. Apply all available knowledge to predict adverse effects and ensure that appropriate humane endpoints are developed and specialist care is provided, especially when using genetically modified animals (e.g., immune deficient or tumour-prone strains)

2. Provide animals with an appropriate environment (e.g., nesting material, shelter for rodents), including sufficient space and complexity to satisfy their normal species-typical behaviours

3. Undertake pilot studies of unfamiliar tumour cell lines or novel procedures to establish experimental and humane endpoints

4. Perform post-mortem examinations as a routine part of all pilot studies and to investigate any unexpected deaths

5. Include appropriate controls to understand individual and combined effects of tumours and treatments

6. Use anaesthesia and analgesia whenever appropriate. This should be regularly reviewed by a vet to ensure that contemporary best practice is followed

7. Consider imaging methods to monitor non-superficial tumour burden and to aid the timely implementation of humane endpoints

8. Do not allow animals to become moribund: death as an intentional endpoint is unacceptable

9. Maintain and share detailed information, on all experimental procedures, including behaviour of the tumour and host animals under various conditions

10. Include principal details relating to the use of animals, such as study design, adverse effects, specialist care and the $3 \mathrm{Rs}$, in all scientific publications

of human (xenogeneic) tumour cells can be achieved using immunodeficient (e.g., nude or SCID) mice to prevent rejection (Table 1A). Most transplantable tumours are established subcutaneously. These subcutaneous (s.c.) tumours are simple to initiate but may lack relevance in terms of stromal/vascular interactions and metastasis. More complex models may involve orthotopic transplantation at appropriate primary sites, or inoculation of tumour cells through routes which maximise the chance of

\section{Box 2 Implementation AND Monitoring}

For assurance that best practice is implemented and rigorously applied, practical guidelines should be clear and readily available, with staff fully engaged and educated in their use

1. Establish a clear chain of responsibility to ensure that prompt action is taken where necessary: for example, if the condition of an animal deteriorates unexpectedly

2. Establish humane endpoints, specialist care, monitoring methods and criteria for intervention between researchers, veterinary and animal care staff before initiating studies

3. Ensure that all staff involved in the use and care of animals are aware of their personal and legal responsibilities, and are trained to recognise adverse effects and apply humane endpoints

4. Seek additional external expertise where unfamiliar models or techniques are being introduced

5. Ensure adequate staffing levels are available for the duration of the study, particularly during crucial periods where additional observations are needed

6. Inspect animals at a frequency determined by the known biology of the tumour, the effects of any interventions and the clinical status of the animals

7. Monitor adverse effects, including general signs of welfare and more detailed indicators appropriate to the specific model and procedures

8. Give all staff appropriate training and professional development opportunities

9. Provide appropriate supervision of staff and confirm, review and document competence on a regular basis

metastatic spread (Table 1B). There is an increasing trend to establish xenograft tumours directly from human cancers, to avoid artificial selection of cells in tissue culture and changes in gene expression and phenotype, which this may induce. Such transplants may better model the principal facets of clinical cancer, for example, maintenance of tumour architecture, heterogeneity, expression of certain targets and response to therapy (Dong et al, 2010), but can be less reproducible (especially as primary grafts) and slower growing than well-established models (Neale et al, 2008; Rubio-Viqueira and Hidalgo, 2009). Detailed molecular and genetic characterisation, facilitated by modern high-throughput technologies (e.g., see http://www.sanger.ac.uk/genetics/CGP), is now available for human cancer cell lines used for xenografts (Masters et al, 2001; Park et al, 2010) and is important to understand the biology of these models and to select the most appropriate for each study.

\section{Autochthonous tumour models}

There are two broad categories: those arising in outbred or inbred rodents (Table 2A), or those from animals harbouring genetic changes that alter tumour susceptibility (Table 2B). Certain mouse or rat strains are susceptible to spontaneous development of tumours. More commonly, tumours are induced by chemical carcinogens, radiation, viruses or bacteria. Such models may mimic some of the aetiological events in human cancer development; exposure to such agents may induce systemic effects that are difficult to replicate in genetically engineered models.

Major advances have been made in the development of sophisticated mouse models of cancer that mimic many of the genetic and biological characteristics of human malignancies, although the host genetic background may affect tumour incidence and/or malignant potential (Lifsted et al, 1998; Winter and Hunter, 2008). A range of technologies now allows the inducible expression of oncogenes or inactivation of tumour-suppressor genes in vivo in a precisely controlled manner in virtually any tissue or cell type. (Chen et al, 2004; Christophorou et al, 2006; Sharpless and DePinho, 2006). Such genetically engineered mouse models 
(GEMMs) provide excellent experimental systems to develop a deeper understanding of cancer biology in vivo and are increasingly being used for preclinical testing of molecularly targeted therapies, as they depend on or are 'addicted' to the specific molecular abnormalities and biochemical pathways engineered to drive the malignant process.

Routine use of GEMMs for preclinical testing of anticancer therapies can be hampered by variable tumour latency, incomplete penetrance and complicated breeding schemes. The full potential of such mouse models is yet to be realised and further work is required to derive maximum benefit for cancer patients from these initiatives (Frese and Tuveson, 2007). Newer models (e.g., exploiting double or multiple genetic abnormalities) have resulted in enhanced tumorigenicity and metastatic capacity, and some studies have shown that mouse cancer models with relevant human gene mutations respond to appropriate targeted therapies (Politi et al, 2006), and also may develop common secondary mutations associated with acquired resistance (Politi et al, 2010). As an example of target validation, reversible, systemic expression of a dominant-negative mutant $\mathrm{Myc}$ oncogene in transgenic Ras-induced lung carcinoma model caused the tumours to regress, whereas effects on normal regenerating tissue were well tolerated and reversible (Soucek et al, 2008). To overcome heterogeneity issues, transplantation of transgenic tumours can provide higher throughput models, for example, for testing therapeutics (Varticovski et al, 2007). Commonly used GEMMs include mammary carcinomas induced by the viral oncogene polyoma virus middle T (Guy et al, 1992; Fluck and Haslam, 1996; Marcotte and Muller, 2008) or by the human or rat Her2/neu oncogene (Chan et al, 1999; Quaglino et al, 2008), or colon adenomas and carcinomas induced by inactivation of the adenomatous polyposis coli (APC) tumour-suppressor gene (Taketo, 2006). Space constraint does not allow a full description or listing of the many more sophisticated, patient-like models now available, examples of which are shown in Table 2B. The reader is referred to the more complete information available at http://emice.nci.nih.gov/ mouse_models.

A key question that continues to be debated is whether human cancer xenografts or murine transgenic models best reflect the human disease in terms of biology and predictions of efficacy of therapeutic agents (Becher et al, 2006; Dennis, 2006; Garber, 2006; Sausville et al, 2006; Sharpless and DePinho, 2006). Some GEMMs have shown patterns of sensitivity to chemotherapeutic agents and development of resistance that are similar to their human tumour counterparts (Rottenberg and Jonkers, 2008). The predictive value of neither type of model has been fully established; however, there is agreement that molecular characterisation of all tumours is required to underpin the choice of model.

\section{Selection and optimisation of experimental systems}

As mentioned, selection of tumour models should be based on both molecular characteristics, for example, expression or mutation of a target of interest or other relevant molecular pathology, either endogenously or through transfection/transgenic technology, together with desired properties such as the rate and reproducibility of growth, metastatic potential and chemosensitivity.

\section{Cell line verification and molecular characterisation}

Given the frequency of misidentification and cross-contamination (Nardone, 2007; Lacroix, 2008) it is essential that all cell lines are rigorously checked for their provenance and genetic identity (Parodi et al, 2002; Yoshino et al, 2006). It is also important that cell lines are free from contamination with infectious agents such as mycoplasma, which can influence their biological behaviour and present a risk to handlers and animals (Ishikawa et al, 2006; Sung et al, 2006; Harlin and Gajewski, 2008). Regardless of origin, detailed characterisation of tumours should be performed and checked periodically to ensure that desired properties are maintained and are commensurate with the molecular pathology of the corresponding human malignancy (Santarius et al, 2010). A thorough literature review should establish their reported tumorigenic and immunogenic properties, with special attention paid to the selection of the correct host animal strain and substrain. Residual immune responses to xenografted tumours in nude/SCID mice may occur and the sex of the host should be

Table IA Transplantable tumour models

\begin{tabular}{|c|c|c|c|}
\hline & Examples of models & Advantages & Disadvantages \\
\hline \multirow[t]{4}{*}{ Syngeneic } & MC26 colon cancer in BALB/c mice & \multirow{4}{*}{$\begin{array}{l}\text { Conventional rodents and normal housing } \\
\text { Covers wide range of tumour types } \\
\text { Models immune and stromal interactions }\end{array}$} & Tend to be aggressive and grow over a short \\
\hline & (Alsheikhly et al, 2004) & & time frame \\
\hline & $\begin{array}{l}\text { B } 16 \text { melanoma in C57/BI mice } \\
\text { (Rusciano et al, 1994) }\end{array}$ & & $\begin{array}{l}\text { Not applicable if investigating human-specific } \\
\text { parameters }\end{array}$ \\
\hline & $\begin{array}{l}\text { 4TI mammary carcinoma in BALB/c mice } \\
\text { (Kim et al, 2009) }\end{array}$ & & $\begin{array}{l}\text { The genetics and histology of tumours may } \\
\text { not reflect the human situation }\end{array}$ \\
\hline \multirow[t]{7}{*}{ Xenogeneic } & HCTI I 6 colon cancer in athymic mice & \multirow{3}{*}{$\begin{array}{l}\text { Allows direct investigation of human cells } \\
\text { Human cancer cell lines are increasingly being } \\
\text { characterised by genetic and other molecular } \\
\text { techniques (Ihle et al, 2009; Bignell et al, 20l0) }\end{array}$} & Requires genetically immunodeficient \\
\hline & (Huxham et al, 2004) & & (nu/nu or SCID) anımals \\
\hline & $\begin{array}{l}\text { PC3 prostate cancer in athymic mice } \\
\text { (Patel et al, 2002) }\end{array}$ & & $\begin{array}{l}\text { Requires sterile isolation and ACDP } \\
\text { containment level-II }\end{array}$ \\
\hline & $\begin{array}{l}\text { Systemic leukaemias in irradiated NOD/SCID } \\
\text { mice (Liem et al, 2004; Lock et al, 2005) }\end{array}$ & \multirow{3}{*}{$\begin{array}{l}\text { Can be an established cell line or human } \\
\text { primary tissue (Neale et al, 2008; } \\
\text { Rubio-Viqueira and Hidalgo, 2009) } \\
\text { Amenable for immune reconstitution }\end{array}$} & $\begin{array}{l}\text { Genetically modified cells will require } \\
\text { ACGM containment }\end{array}$ \\
\hline & GFP transgenic mice to enhance visualisation & & \multirow{3}{*}{$\begin{array}{l}\text { May not be suitable for use with agents } \\
\text { modifying the immune system or where } \\
\text { cellular interactions are being investigated }\end{array}$} \\
\hline & of tumour-host interactions (Yang et al, 2004) & & \\
\hline & $\begin{array}{l}\text { Luciferase-expressing cancer cells for } \\
\text { bioluminescent imaging (Dickson et al, 2007; } \\
\text { Comstock et al, 2009; Shibata et al, 2009) }\end{array}$ & Can be grown s.c. or orthotopically & \\
\hline
\end{tabular}

Abbreviations: ACDP = Advisory Committee on Dangerous Pathogens; ACGM = Advisory Committee on Genetic Modification; GFP = green fluorescent protein; NOD = nonobese diabetic; s.c. = subcutaneous; SCID = severe combined immunodeficient. 
Table IB Transplantation models used for therapeutic studies

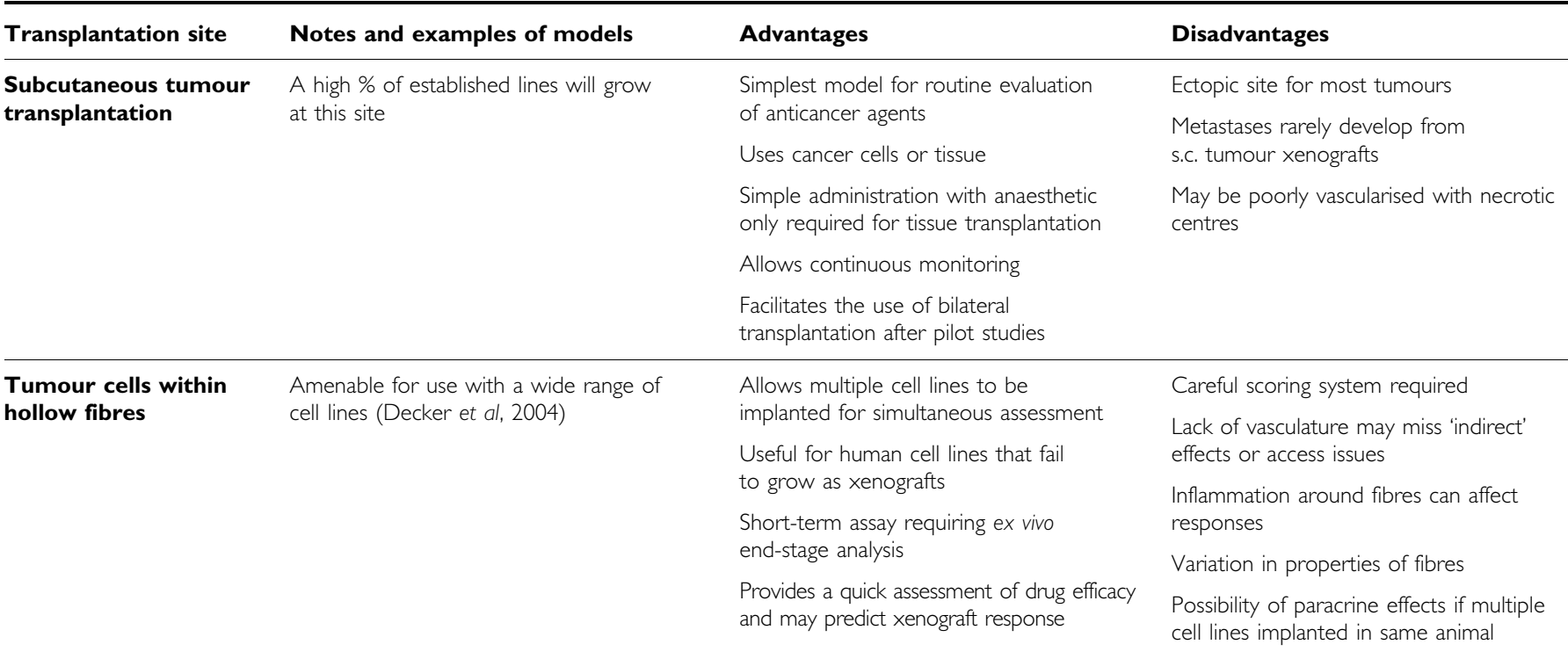

\section{Experimental metastasis \\ (site of spread) \\ Intravenous}

(primarily lung)
3DCI3B lymphoma (Golay et al, 2006)

M24met melanoma (Becker et al, 1996)

A549 NSCLC (Kennel et al, 1999)

Lewis lung 3LL (Li et al, 200I)
Intra-peritoneal-(ascites and peritoneal/ omentum-associated tumours)

Intra-tibial ${ }^{\mathrm{a}}$ (bone)
GW-39 colon (Sharkey et al, |991)

MGLVAI gastric (Watson et al, 1999b)

OVCAR3 ovarian (Zavaleta et al, 2008)

ARCaP prostate (Zhau et al, 2000)
Intra-cardiac ${ }^{\mathrm{a}}$ (bone)

MDA MB 23I breast (Serganova et al, 2009)

A375 melanoma (Nakai et al, 1992)

Mat Ly-lu prostate (Blouin et al, 2008)

Intra-portal

vein (liver, nodes)

Intrasplenic (liver)
LSI74T colon (Mahteme et al, 1998)

WiDR colon (Miyazaki et al, 1999)
Most cells injected i.v. colonise lung

Some (notably lymphoid tumours) may colonise other organs

Models end-stage of metastasis in a controlled manner

Simple model to establish

Cells may be tagged for imaging

Mimics late-stage ovarian cancer and carcinomatosis associated with some abdominal cancers

Mimics bone tumour growth seen with myeloma or prostate and breast cancer metastases

To some extent mimics the dissemination phase of metastasis

Localises tumour cells to liver

Appropriate for colon, pancreatic and breast cancers

Easier procedure than mesenteric vein or intraportal cell inoculation
Bolus injection of cells does not mimic natural dissemination and the 'conditioning' effect of primary tumour growth

Does not model the full spectrum of metastatic cascade

Difficult to monitor and quantify accurately without imaging

Pilot studies required to establish incidence and growth kinetics

Difficult to quantify

Does not mimic natural tumour dissemination

Risk of infection and pain

Requires imaging

Requires advanced surgical technique Risky procedure requiring particular care

Only suitable for a limited number of cell lines

Requires advanced surgical technique to avoid cell leakage into peritoneal cavity

Local growth in spleen may complicate the interpretation of results unless splenectomy is performed

\section{Orthotopic and spontaneous metastasis models \\ (sites of metastasis) \\ Intra-caecal/lymphoid \\ follicle (liver) \\ Intra-dermal (lung/nodes/liver) \\ Mammary fat pad (lungs/nodes/brain) \\ TK-3,-4,-9 colon (Tanaka et al, 1995) \\ NC65 renal (Nakatsugawa et al, 1999) \\ A-07melanoma (Graff et al, 2005) \\ MDA-MB-23 I breast (Serganova et al, 2009) \\ 4TI breast (murine) (Mitra et al, 2006)}

Relevant stromal/vascular cell interactions

Models the full metastatic cascade

Certain models may involve lymph node spread

Cells may be genetically tagged to

allow real-time imaging

Chemosensitivity more relevant 
Table IB (Continued)

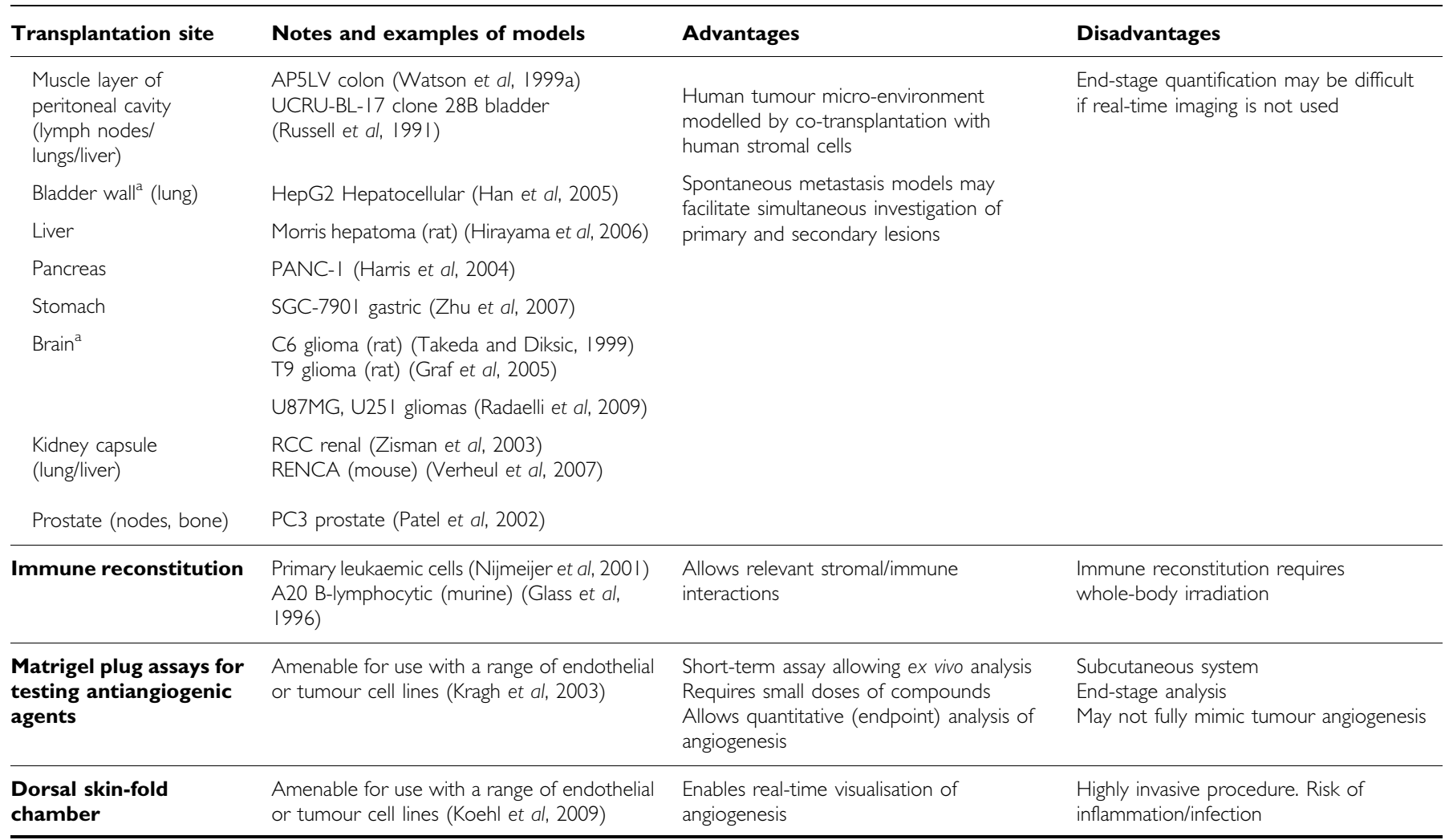

Abbreviation: i.v. $=$ intravenously. ${ }^{\text {a }}$ These models are specialised and not recommended for routine use. All examples involve human cell lines unless indicated as rodent.

considered, particularly for hormone-responsive tumours such as breast and prostate.

\section{Pilot studies and optimisation}

Pilot tumour growth studies using small numbers of animals $(5-10)$ are recommended to establish that patterns of local and metastatic growth are reproducible. They also show any adverse effects associated with tumour progression and enable humane endpoints to be identified. The data derived should feed into group numbers used for definitive studies (e.g., therapy experiments) in order for experimental time frames and statistically significant endpoints to be established. Use of a relevant positive control treatment may be useful at this stage to ensure that tumour growth/ responsiveness is as expected. This can be dictated by a variety of factors, including the site of growth. Subcutaneous tumours may grow rapidly and some are prone to developing haemorrhagic areas, which can cause rapid expansion and ulceration (e.g., human A2780 ovarian carcinoma and AR42J pancreatic carcinoma xenografts).

For tumours growing as a suspension in the peritoneal cavity, it is important to establish clear criteria to ensure that studies are terminated before animal welfare is compromised. This site is only appropriate for models where ascites is a feature of the natural progression of the human cancer (e.g., ovarian carcinoma, peritoneal mesothelioma, gastrointestinaI tumour carcinomatosis). Similar criteria apply to other sensitive specialised sites such as muscle or brain. For metastatic models, pilot experiments should define the extent and time course of dissemination to internal organs.

Pilot studies should include sequential analysis of animals to determine the time course required to achieve scientific goals. Termination of studies at the earliest possible point will minimise adverse effects on the animal. Where possible, use of biomarkers (e.g., serum levels of prostate-specific antigen, PSA) and real-time imaging are highly recommended. It is also possible to measure circulating tumour cells using fluorescence and PCR-based techniques (Glinskii et al, 2003; Komatsubara et al, 2005). For spontaneously arising tumours, including those in transgenic animals, particular attention should be paid to the time course of tumour development and issues relating to the development of multiple tumours. Progression may be unpredictable and involve rapid dissemination and subsequent deterioration in clinical condition, in which case careful and frequent monitoring is required.

\section{Refinement and welfare issues}

Subcutaneous implantation of tumour material should use a trochar or surgical formation of a small s.c. pocket. Appropriate anaesthetics must be used and post-implantation analgesia is also strongly recommended. Veterinary advice should be sought to ensure that the agents selected reflect contemporary best practice. Anaesthesia/ analgesia is also required for implantation of 'hollow fibres' or slow release devices such as osmotic mini-pumps. Hormone pellets (oestrogen/testosterone) may be required to support hormonedependent tumours, but first-time use in a particular strain will require pilot experiments with different doses/exposures to assess tolerance, especially with oestrogen pellets where urinary tract side effects may be encountered (Pearse et al, 2009).

For injection of cell suspensions, the minimum number of cells in the smallest volume should be used, consistent with the properties of the tumour. For s.c. sites, $1-5$ million cells in $100 \mu \mathrm{l}$ is typical. For orthotopic sites, this should be reduced to avoid excessive tissue damage or leakage (e.g., 50000 cells in $30 \mu$ l into the prostate, or $10-50000$ cells in $5 \mu \mathrm{l}$ into the brain). Intramuscular tumours in the leg can affect mobility, and this site should only be used if there is special justification (e.g., for tumours which naturally develop in this tissue). Similarly, footpad 
injection, which has been traditionally used to potentiate lymphatic dissemination, is unacceptable without exceptional scientific justification and should then only involve a single paw.

Surgical removal of a primary tumour may be justified, for example, from s.c. sites, mammary fat pad or removal of the spleen following intrasplenic injection, to allow time for outgrowth of any secondary deposits. Surgery must be performed using sterile techniques with appropriate post-operative monitoring and control of any pain and inflammation/infection.

Cell lines should be checked regularly for contaminating microorganisms to avoid infection of host animals. This is especially important if tumours are routinely passaged between animals, which may be justified for those that are difficult to establish from cell cultures. Asymptomatic infection of experimental animals may affect tumour properties, for example, metastasis (Rodriguez-Cuesta et al, 2005). Procedures can be used to improve tumour take rate. For example, moderate doses of whole-body irradiation may further enhance engraftment of tumour cells in athymic mice (Baersch et al, 1997; Nijmeijer et al, 2001; Li et al, 2006), although the added stress and risk to the animal must be considered. Co-administration of human tumour cells with allogeneic bone marrow transplantation may reduce graft- $v s$-host activity but preserve graft- $v s$-tumour effects in allogeneic leukaemia models (Prigozhina et al, 2002; Giver et al, 2004).
Transplanted tumours (especially xenografts) may not develop with an incidence, growth rate or malignant potential required; however this can often be enhanced by selection of tumorigenic/metastatic variants (Bruns et al, 1999; Nguyen et al, 2009a). In addition, co-injection of tumour cells with extracellular matrix proteins and/or angiogenic factors (Collado et al, 2007), cancer-associated fibroblasts (Noel et al, 1993; Orimo et al, 2005) or mesenchymal stem cells (Karnoub et al, 2007; Spaeth et al, 2009) can increase tumorigenicity, better recapitulate the human tumour microenvironment and enhance metastatic potential. Cells may be transfected with fluorescent or bioluminescent markers allowing serial imaging of internal tumours/metastatic spread. However, such tagged cell lines should be profiled to establish that their biological characteristics are unchanged and consideration should be given to the dependence of luminescence/fluorescence on factors in the tumour microenvironment, for example. molecular oxygenation, necrosis, or ascites fluid from peritoneal tumours (Condeelis and Segall, 2003).

\section{THERAPY}

\section{Preclinical discovery and development of therapeutics}

There is a concerted effort to identify and develop small-molecule drugs or biopharmaceuticals (e.g., antibodies, protein therapeutics,

Table 2A Primary tumour models

\begin{tabular}{|c|c|c|c|}
\hline Model type & Examples of models & Advantages & Disadvantages \\
\hline \multirow[t]{7}{*}{$\begin{array}{l}\text { Chemically-induced } \\
\text { tumours }\end{array}$} & $\begin{array}{l}\text { Dimethyl hydrazine - gastric cancer } \\
\text { (Watanabe et al, 1999) }\end{array}$ & $\begin{array}{l}\text { Model the full spectrum of carcinogenic } \\
\text { events }\end{array}$ & $\begin{array}{l}\text { Low incidence and heterogeneous } \\
\text { tumour development }\end{array}$ \\
\hline & Azoxymethane - colon cancer (Hirose et al, 2004) & \multirow[t]{6}{*}{ Useful in chemoprevention studies } & \multirow{2}{*}{$\begin{array}{l}\text { Safety aspects associated with use of } \\
\text { carcinogens - may need to house } \\
\text { animals in isolator }\end{array}$} \\
\hline & $\begin{array}{l}\text { Diethylnitrosamine - heptaocellular carcinoma } \\
\text { (Ha et al, 200I) }\end{array}$ & & \\
\hline & $\begin{array}{l}\text { Dimethyl benzanthracene - breast cancer } \\
\text { (Hawariah and Stanslas, 1998) }\end{array}$ & & $\begin{array}{l}\text { Long time frame for tumour } \\
\text { development }\end{array}$ \\
\hline & \multirow{2}{*}{$\begin{array}{l}N \text {-acetylcysteine - squamous oesophageal } \\
\text { carcinoma (Balansky et al, 2002) }\end{array}$} & & \multirow{2}{*}{$\begin{array}{l}\text { Continuous monitoring not feasible } \\
\text { Often highly immunogenic }\end{array}$} \\
\hline & & & \\
\hline & $\begin{array}{l}\text { Dimethylbenzanthracene/ } \\
\text { tetradecanoyl phorbol acetate (TPA) } \\
\text { - skin cancer (Johansen et al, 2009) }\end{array}$ & & \\
\hline \multirow[t]{2}{*}{$\begin{array}{l}\text { Radiation-induced } \\
\text { tumours }\end{array}$} & \multirow[t]{2}{*}{$\begin{array}{l}\text { Ultraviolet light (Ahsan et al, 2005; } \\
\text { De Fabo, 2006; El-Abaseri and Hansen, 2007) }\end{array}$} & $\begin{array}{l}\text { Models non-melanoma (using UVA) and } \\
\text { melanoma (UVB) skin cancer }\end{array}$ & \multirow[t]{2}{*}{ Requires hairless mice } \\
\hline & & Useful for prevention (e.g.. sunscreen) studies & \\
\hline \multirow{3}{*}{$\begin{array}{l}\text { Inflammation- } \\
\text { induced tumours }\end{array}$} & \multirow{3}{*}{$\begin{array}{l}\text { Helicobacter pylori-induced gastric } \\
\text { cancer in gerbils (Zheng et al, 2004) }\end{array}$} & Use of conventional rodents to facilitate & \multirow{3}{*}{$\begin{array}{l}\text { Limited availability of models } \\
\text { Long time frame and variability } \\
\text { in tumour development }\end{array}$} \\
\hline & & $\begin{array}{l}\text { the involvement of the full spectrum of } \\
\text { immune mediators }\end{array}$ & \\
\hline & & $\begin{array}{l}\text { Models malignant progression and amenable } \\
\text { for use of chemopreventive agents }\end{array}$ & \\
\hline \multirow[t]{2}{*}{$\begin{array}{l}\text { Surgically-induced } \\
\text { tumours }\end{array}$} & \multirow[t]{2}{*}{$\begin{array}{l}\text { Oesophago-gastroduodenal anastomosis model } \\
\text { of oesophageal carcinogenesis (Chen et al, 1999) }\end{array}$} & \multirow[t]{2}{*}{$\begin{array}{l}\text { Can model malignant progression or } \\
\text { metastatic spread }\end{array}$} & $\begin{array}{l}\text { High level of skill required for initiation } \\
\text { Incidence may not be } 100 \%\end{array}$ \\
\hline & & & $\begin{array}{l}\text { Accurate quantification can be difficult } \\
\text { unless using real-time imaging }\end{array}$ \\
\hline \multirow{3}{*}{$\begin{array}{l}\text { Spontaneous } \\
\text { tumours, } \\
\text { sometimes with } \\
\text { viral/genetic } \\
\text { component }\end{array}$} & \multirow{2}{*}{$\begin{array}{l}\text { TI38 mice and mammary carcinoma } \\
\text { (Wood et al, 1992; Nordsmark et al, 1996) } \\
\text { Cotton rats and neuroendocrine gastrointestinal } \\
\text { tumours (Martinsen et al, 2003) }\end{array}$} & \multirow{3}{*}{$\begin{array}{l}\text { Develop cancer without any intervention } \\
\text { Conventional rodents, therefore fully } \\
\text { immunocompetent }\end{array}$} & \multirow{3}{*}{$\begin{array}{l}\text { Limited tumour types and strains } \\
\text { Variability in the time frame of tumour } \\
\text { development }\end{array}$} \\
\hline & & & \\
\hline & $\begin{array}{l}\text { Eker rat model of tuberous sclerosis } \\
\text { (Kenerson et al, 2005) }\end{array}$ & & \\
\hline
\end{tabular}


Table 2B Genetically engineered mouse models (GEMMs)

\begin{tabular}{|c|c|c|c|c|c|}
\hline $\begin{array}{l}\text { Examples of } \\
\text { models }\end{array}$ & $\begin{array}{l}\text { Spectrum of } \\
\text { tumours }\end{array}$ & $\begin{array}{l}\text { Spectrum of tumours } \\
\text { in humans }\end{array}$ & $\begin{array}{l}\text { Recent genetic } \\
\text { modifications }\end{array}$ & $\begin{array}{l}\text { Spectrum of tumours } \\
\text { in modified models }\end{array}$ & References \\
\hline $\mathrm{Rb}$ & Brain, pituitary & $\begin{array}{l}\text { Retinoblastoma, } \\
\text { osteosarcoma, } \\
\text { medulloblastoma }\end{array}$ & $\begin{array}{l}\text { Additional loss of pl07, } \\
\text { pl30 }\end{array}$ & Retinoblastoma & $\begin{array}{l}\text { (Robanus-Maandag } \\
\text { et al, 1998) }\end{array}$ \\
\hline Trp53 & $\begin{array}{l}\text { Osteosarcoma, } \\
\text { lymphoma, soft-tissue } \\
\text { sarcoma, germ cell } \\
\text { tumours }\end{array}$ & $\begin{array}{l}\text { Breast carcinoma, brain, } \\
\text { sarcomas, leukaemia, } \\
\text { endocrine }\end{array}$ & $\begin{array}{l}\text { Additional loss of Terc } \\
\text { Trp53(ER)TAM }\end{array}$ & $\begin{array}{l}\text { Breast and other } \\
\text { carcinomas, germ-cell } \\
\text { tumours }\end{array}$ & $\begin{array}{l}\text { (Artandi et al, 2000) } \\
\text { (Christophorou et al, } \\
\text { 2005) }\end{array}$ \\
\hline $\begin{array}{l}\text { Apc (ApcMIN, } \\
\text { ApcD7I6, } \\
\text { ApcD580) }\end{array}$ & $\begin{array}{l}\text { Multiple polyps in small } \\
\text { intestine }\end{array}$ & $\begin{array}{l}\text { Polyps in colon progressing } \\
\text { to carcinomas }\end{array}$ & $\begin{array}{l}\text { Conditional colon-specific } \\
\text { inactivation }\end{array}$ & $\begin{array}{l}\text { Polyps in colon } \\
\text { Mammary carcinoma }\end{array}$ & (Shibata et al, 1997) \\
\hline Ink4a & $\begin{array}{l}\text { Fibrosarcoma, lymphoma, } \\
\text { squamous-cell carcinoma }\end{array}$ & $\begin{array}{l}\text { Familial melanoma, sporadic } \\
\text { pancreatic, brain tumours }\end{array}$ & Crossed with Arf + /- mice & $\begin{array}{l}\text { Metastatic melanoma, } \\
\text { sarcoma, carcinoma, } \\
\text { lymphoma }\end{array}$ & $\begin{array}{l}\text { (Krimpenfort et al, } \\
2001 \text { ) }\end{array}$ \\
\hline Brcal & No tumour susceptibility & Breast ovary & $\begin{array}{l}\text { Conditional mammary- } \\
\text { specific inactivation of Brcal }\end{array}$ & Mammary tumours & (Xu et al, 1999) \\
\hline Brca2 & No tumour susceptibility & Breast, ovary & $\begin{array}{l}\text { Conditional mammary- } \\
\text { specific inactivation of } \\
\text { Brca2 and Trp53 }\end{array}$ & Mammary tumours & (Jonkers et al, 200I) \\
\hline $\mathrm{Nfl}$ & $\begin{array}{l}\text { Pheochromocytoma, } \\
\text { myeloid leukaemia }\end{array}$ & $\begin{array}{l}\text { Neural-crest-derived benign } \\
\text { neurofibroma and malignant } \\
\text { fibrosarcoma }\end{array}$ & Additional loss of Trp53 & $\begin{array}{l}\text { Neural-crest-derived } \\
\text { malignant glioblastoma }\end{array}$ & (Reilly et al, 2000) \\
\hline $\mathrm{Nf2}$ & $\begin{array}{l}\text { Osteosarcoma, } \\
\text { fibrosarcoma, lung } \\
\text { adenocarcinoma, } \\
\text { mepatocellular carcinoma }\end{array}$ & $\begin{array}{l}\text { Schwannomas, } \\
\text { meningiomas, } \\
\text { ependymomas, gliomas }\end{array}$ & $\begin{array}{l}\text { Schwann-cell precursor- } \\
\text { specific ablation of } \mathrm{Nf2}\end{array}$ & Schwannomas & (Giovannini et al, 2000) \\
\hline K-ras ${ }^{G 12 D}$ & $\begin{array}{l}\text { Lung adenoma, } \\
\text { adenocarcinoma } \\
\text { PanIN }\end{array}$ & NA & $\begin{array}{l}\text { Mutant Trp53 } \\
\text { Pancreas-specific } \\
\text { K-ras }{ }^{\text {GI2D }}+\text { Ink4a/Arf } \\
\text { deficiency or combined } \\
\text { withTrp53 }\end{array}$ & $\begin{array}{l}\text { Metastatic lung cancer } \\
\text { Metastatic pancreatic } \\
\text { cancer }\end{array}$ & $\begin{array}{l}\text { (Johnson et al, 200I) } \\
\text { (Aguirre et al, 2003; } \\
\text { Hingorani et al, 2005) }\end{array}$ \\
\hline $\begin{array}{l}\text { AMLI/ETO or } \\
\text { MLL fusion } \\
\text { proteins }\end{array}$ & AML & AML & & & (Zuber et al, 2009) \\
\hline MYCN & $\begin{array}{l}\text { Neuroblastoma, } \\
\text { Rhabdomyosarcoma, } \\
\text { medulloblastoma }\end{array}$ & $\begin{array}{l}\text { Neuroblastoma, } \\
\text { Rhabdomyosarcoma, } \\
\text { medulloblastoma }\end{array}$ & $\begin{array}{l}\text { TH-driven overexpression } \\
\text { in neural crest }\end{array}$ & & (Weiss et al, 1997) \\
\hline MYCC & $\begin{array}{l}\text { Pancreatic adenoma, } \\
\text { melanoma, lymphoma, } \\
\text { AML, breast }\end{array}$ & $\begin{array}{l}\text { Pancreatic adenoma, } \\
\text { melanoma, lymphoma, } \\
\text { AML, breast }\end{array}$ & $\begin{array}{l}\text { BCL-XL crosses } \\
\text { Lck overexpression } \\
\text { Eu-Tta-c-myc } \\
\text { MMTV-c-myc }\end{array}$ & & $\begin{array}{l}\text { (Pelengaris et al, 1999) } \\
\text { (Felsher and Bishop, } \\
\text { 1999) } \\
\text { (Sinn et al, 1987) }\end{array}$ \\
\hline Ptcl & Medulloblastoma & & Trp53-knockout crosses & & (Wetmore et al, 200l) \\
\hline T-antigen & $\begin{array}{l}\text { Pancreatic } \\
\text { adenocarcinoma }\end{array}$ & & $\begin{array}{l}\text { RIPI-Tag2 driven } \\
\text { overexpression in pancreatic } \\
\text { islets }\end{array}$ & & (Bergers et al, 1999) \\
\hline PTEN & $\begin{array}{l}\text { Breast, endometrial, } \\
\text { glioblastoma, prostate, } \\
\text { and thyroid carcinoma, } \\
\text { Cowden syndrome, } \\
\text { hamartomas, urothelial } \\
\text { tumours of renal pelvis }\end{array}$ & $\begin{array}{l}\text { Breast, endometrial, } \\
\text { glioblastoma, prostate, and } \\
\text { thyroid carcinoma, Cowden } \\
\text { syndrome, hamartomas, } \\
\text { urothelial tumours of renal } \\
\text { pelvis }\end{array}$ & & & $\begin{array}{l}\text { (Stambolic, 2000; } \\
\text { Qian, 2009) }\end{array}$ \\
\hline
\end{tabular}

Abbreviations: $\mathrm{AML}=$ acute myeloid leukaemia; $\mathrm{NA}=$ not available; PanlN, pancreatic intraepithelial neoplasia.

vaccines, gene therapy) targeted against cancer cells or associated host cells (Sawyers, 2004; Collins and Workman, 2006; Workman and de Bono, 2008). A representative 'test cascade' for discovering new small-molecule inhibitors of cancer targets is shown in Figure 2. As a consequence of extensive in vitro testing, comparatively small numbers of prioritised compounds progress to examination in vivo (Collins and Workman, 2006). In vivo studies use sequential, discriminatory tests to prioritise compounds at each stage. Different tests may need to be applied to biopharmaceuticals, such as antibodies and vaccines, as they may work by recruiting host effectors (e.g., cytotoxic leukocytes). Epitope specificity can also require the development of an antibody or vaccine initially using anti-rodent reagents (before switching to the clinical form) or use of a genetically modified mouse model. In addition, agents directed 

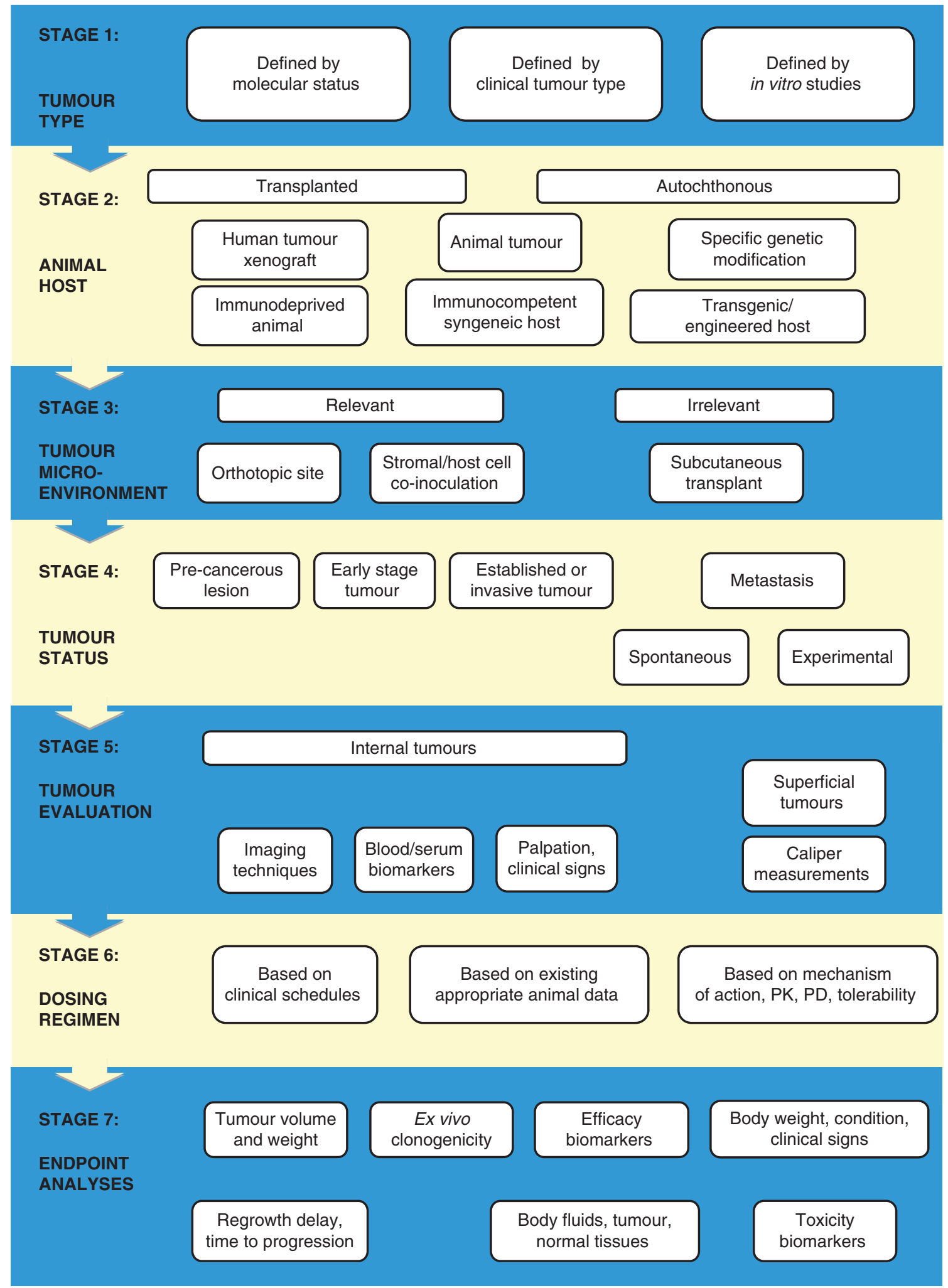

Figure I An illustrative process for tumour model selection and use. This representative schema provides an illustration of factors to be considered when designing an animal study. In this particular example, all the factors listed at a given stage (and potentially others) should be considered before moving down, stepwise, to the next stage. Here, an initial consideration is that the choice of model may be based on the relevant molecular status, clinical tumour type or in vitro studies. At the next stage, the animal host will be dictated by the need for, say, a human tumour xenograft versus a genetically engineered mouse model, which have advantages discussed in the text. Considerations of tumour environment and site then follow, after which, in therapy studies, are dosing and endpoint aspects. Note that this schema is illustrative and not prescriptive and that each study must be tailored to the specific scientific question and experimental objectives, with appropriate humane endpoints always applied and pilot studies carried out as needed. 


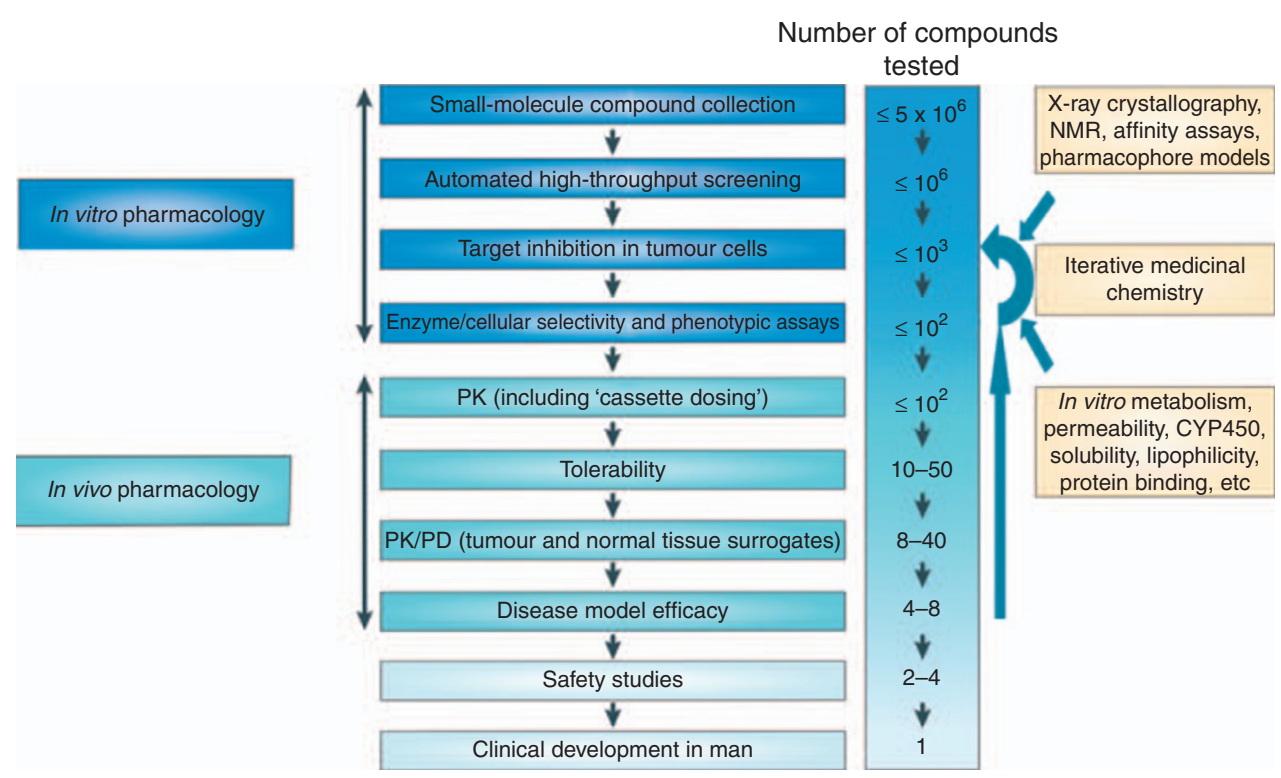

Figure 2 Example of a drug discovery test cascade for identifying small-molecule antitumour drugs. A representative test cascade for identifying a potential small-molecule drug against a given target is shown. A subset of a compound library is initially screened vs the target in vitro, in recombinant protein or cellular assays, using high-throughput automation to identify 'hits'. Subsequent leads are examined in more detail by assessing their effect on downstream molecular events in cells and their selectivity vs other proteins. A battery of additional in vitro tests is also used for measurement or prediction of physical properties and pharmacokinetic parameters. Only compounds with a promising balance of features are progressed to in vivo testing, usually in mice. Pharmacokinetic (PK) studies, used to understand drug exposure, may initially involve co-inoculation of low doses of compounds ('cassette dosing') to minimise animal usage. The tolerability of leads with favourable PK is then assessed at higher doses, before evaluating their pharmacodynamic (PD) effect on tumour and normal tissues at well-tolerated doses. Compounds that do not meet the anticipated level of performance at any stage may result in subsequent rounds of iterative medicinal chemistry to generate improved leads. Selected leads are progressed to efficacy testing to determine the link between target inhibition and the effect on tumour growth or spread (metastasis). Safety studies on late-stage leads are also required before a candidate drug can be selected for examination in cancer patients (not covered here). The application of the test cascade means that compounds are filtered by the earlier stage assays so that a smaller number of compounds, and only those of higher quality, are taken into later stage in vivo assays in animals.

against the tumour microenvironment (e.g., angiogenesis, tumourpromoting stromal or inflammatory cells) will require appropriate specialised assays. A range of technical platforms are used preclinically to define responses to therapy, the most informative of which are adopted for use in patients (Figure 3). Careful assessment of a therapy's safety profile (outside the scope of this review) is also required for regulatory submission.

\section{Defining tolerable doses for efficacy studies}

An investigational treatment should be examined at a potential therapeutic dose level and using a relevant dosing regimen that covers the longest duration anticipated. These parameters can, for example, be estimated from consideration of mechanism of action, in vitro potency, pharmacokinetics, protein binding and pharmacodynamic biomarker data. Studies typically use two mice per dose level with a doubling dose-escalation or dose-halving de-escalation design. For studies involving a single dosing event, an interval of $24 \mathrm{~h}$ should be used before an alternative dose level is examined, to allow any acute adverse effects to be seen. For more chronic administration schedules (e.g., daily for 21-28 days) this interval should be at least 5 days. Animals should be examined at least twice daily (see humane endpoints below). Note that presence of a tumour may reduce host tolerance to therapy. Studies of mice may be used to predict dose requirements in other species through allometric scaling of pharmacokinetic parameters (Freireich et al, 1966).

\section{Combination studies}

There is a strong rationale to study combinations of agents in vivo to guide clinical studies. Relevant prior in vitro studies such as Combination Index or isobologram analyses to discriminate additive, synergistic or antagonistic interactions should be completed to guide the selection of combinations and schedules. Compounds are added to tumour cells in culture over a range of concentrations, alone or in combination, and the changes in sensitivity are observed. Compounds may also be added sequentially as the order of administration may significantly influence responses (Chou, 2006). Care needs to be taken with in vivo studies in addressing the choice of individual drug doses and scheduling, particularly if overlapping toxicities are likely. Pilot experiments must assess tolerability (see above), and pharmacokinetic data (see below) should also be generated to determine whether interpretation of efficacy data is affected by pharmacokinetic interactions (Siim et al, 2003).

\section{Pharmacokinetic studies}

In vitro and in silico methods are useful to predict absorption, distribution, metabolism and elimination (ADME) properties and to help prioritise compounds for evaluation in animals (Table 3; Singh, 2006). However, at present such methods are unable to predict accurately the full pharmacokinetic profile of an agent. Pharmacokinetic studies should use a validated and sufficiently sensitive detection method, ideally avoiding the need to pool separate blood samples, thereby minimising animal usage. Typical experiments on mice use a single dose and 5-8 time points $(2-3$ mice per point) over $24-48 \mathrm{~h}$ with small molecules (usually administered p.o., i.v. or i.p. at doses of $0.5-100 \mathrm{mg} \mathrm{kg}^{-1}$ ) and over 1-21 days with biopharmaceuticals (administered i.v., i.p. or s.c. at doses ranging from 10 to $1000 \mu \mathrm{g}$ per mouse).

More recently, repeat sampling of small volumes of blood from a superficial vein in mice over a series of time points has been established to reduce animal numbers. This can be employed either for isolation of plasma and analysis by sensitive liquid 
(b)

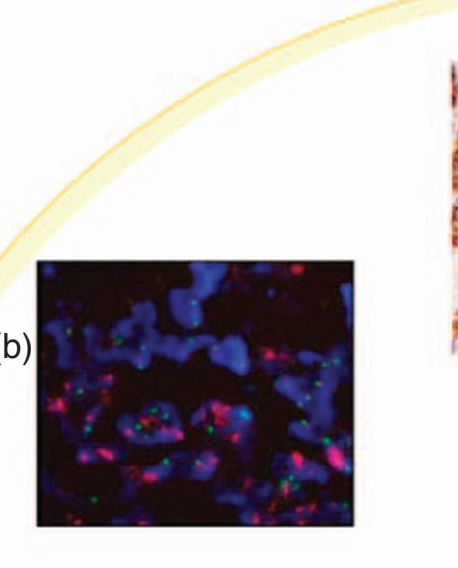

(c)

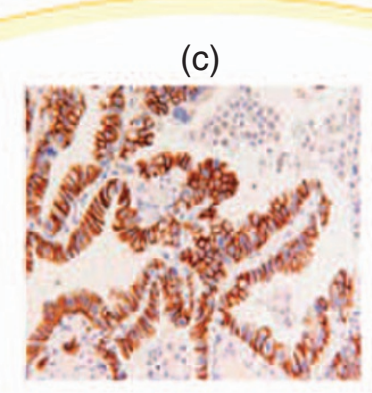

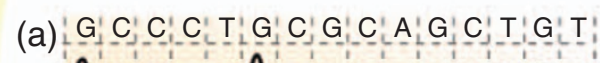
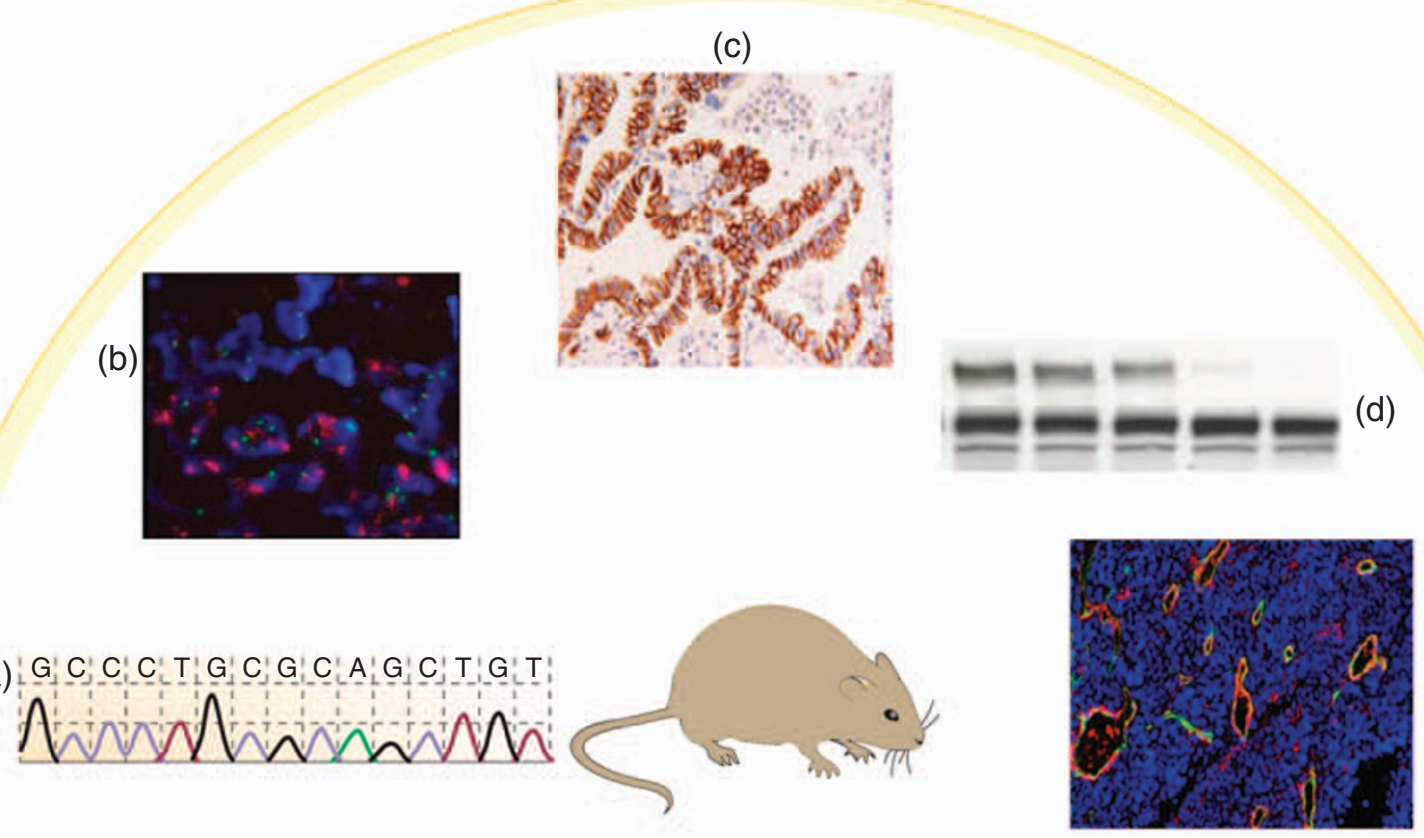

(e)
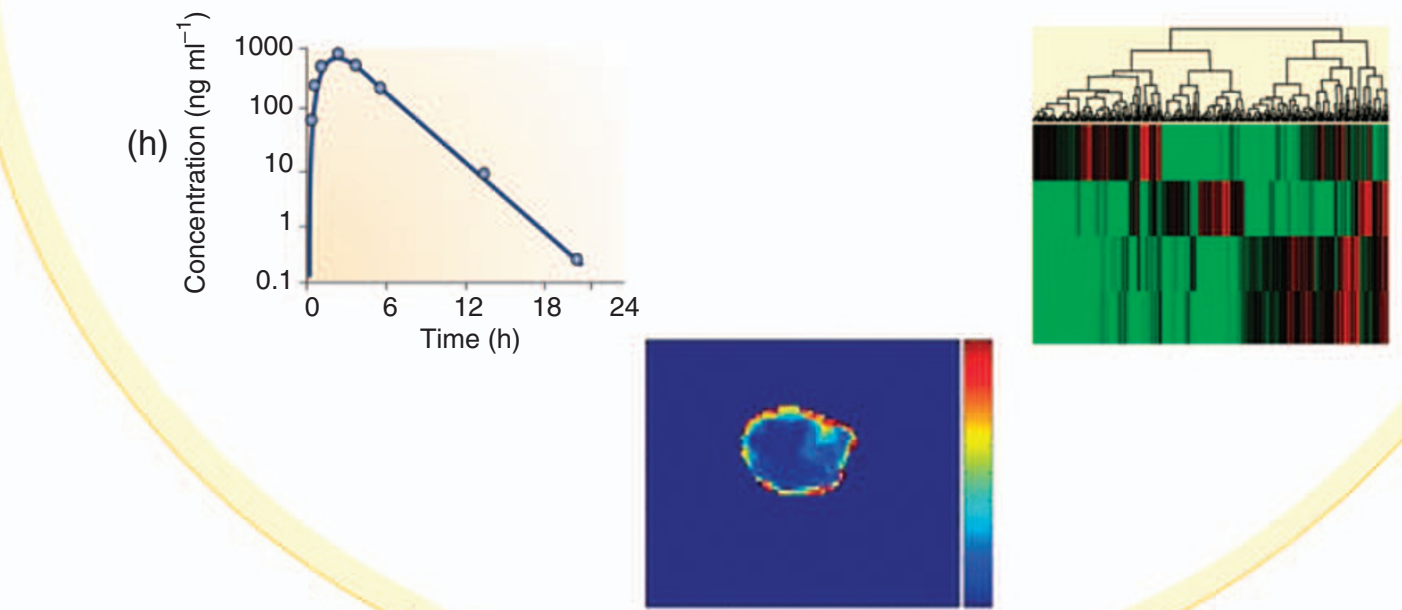

(f)

(g)

Figure 3 Examples of technologies used in animals for therapeutic cancer research. In vivo tumour models have an essential role in the development of new cancer medicines, enabling the temporal and quantitative effects of treatment to be examined on tumour and normal tissues in the intact organism. Methods used include those to examine (clockwise from far left) molecular determinants of sensitivity to treatment (initially in vitro, corroborated in vivo) such as (a) gene mutations by sequencing, or (b) gene amplification by fluorescent in situ hybridisation; detection of target phospho-epitopes and their inhibition in tumour tissue as determined by: (c) immunohistochemistry or (d) western blotting of cell lysates; (e) tumour vascular density and maturation by fluorescent immunohistochemistry; (f) tumour mRNA expression by gene array analysis with hierarchical clustering of information; (g) imaging techniques such as dynamic contrast-enhanced MRI to measure tumour haemodynamics; and (h) pharmacokinetic analysis of drug concentrations in plasma by mass spectrometry.

chromatography-mass spectrometry/mass spectrometry (LC/MSMS or tandem MS) instrumentation (Abatan et al, 2008), or by spotting microlitre volumes of whole blood onto specialised paper cards, which are then dried and extracted before analysis (Barfield et al, 2008). In rats, a 5-8 time-point pharmacokinetic profile may be generated using 2-6 animals in total, through repeated blood sampling. 'Cassette dosing', which involves administration of low doses of compound mixtures, should also be considered initially as this can reduce animal usage (Watanabe et al, 2006; Smith et al, 2007). Wherever possible, computational compartmental kinetic modelling should be used to predict optimal doses or multiple dosing protocols, to facilitate more limited sampling (Rowland and
Tozer, 1995). It is noteworthy that the plasma half-life of monoclonal antibodies is frequently extended in immunocompromised mice, which are deficient in IgG production (Bazin et al, 1994).

\section{Pharmacodynamic biomarkers}

Initial studies of investigational therapies using tumour-bearing animals should aim to determine whether the target, or an appropriate downstream pathway or phenotype, is modulated by using suitably validated pharmacodynamic biomarkers (Collins and Workman, 2006). Typically, animals are humanely killed at intervals to determine the extent and duration of 
pharmacodynamic changes and to investigate biomarkers in tumour and normal tissues (e.g., blood or skin) that may be relevant to clinical development (Banerji et al, 2005). In vaccine studies, responses are assessed by changes in immune status,

Table 3 Some in vitro assays for pharmacokinetic/ADME properties

\begin{tabular}{|c|c|}
\hline Property & Assays \\
\hline Chemical and physical properties & $\begin{array}{l}\text { In silico predictions or in vitro } \\
\text { measurements of logP (Mannhold et al, } \\
\text { 2009), logD (Bruneau and McElroy, } \\
\text { 2006; Dohta et al, 2007), pK } K_{\mathrm{a}} \text { (Lee et al, } \\
\text { 2007) and solubility (Colclough et al, } \\
\text { 2008; Du-Cuny et al, 2008) }\end{array}$ \\
\hline Metabolism & $\begin{array}{l}\text { Mouse, rat, human liver } \\
\text { microsomes, hepatocytes, S9 } \\
\text { incubations, UGT assays } \\
\text { (Houston and Carlile, 1997; } \\
\text { Riley et al, 2002) }\end{array}$ \\
\hline Passive diffusion/cell uptake & PAMPA (Ottaviani et al, 2006) \\
\hline Cell and gut permeability predictions & Caco-2 cells (Artursson et al, 200I) \\
\hline $\begin{array}{l}\text { Blood-brain barrier permeability } \\
\text { predictions }\end{array}$ & hCMEC/D3 cells (Poller et al, 2008) \\
\hline $\begin{array}{l}\text { Drug-drug interactions } \\
\text { (e.g., CYP450) }\end{array}$ & $\begin{array}{l}\text { Human liver microsomes, } \\
\text { hepatocytes, CYP enzyme screens } \\
\text { (Masimirembwa et al, 200I) }\end{array}$ \\
\hline Protein binding & $\begin{array}{l}\text { Measurement by dialysis or } \\
\text { ultrafiltration (Howard et al, 2010) }\end{array}$ \\
\hline
\end{tabular}

Abbreviations: $A D M E=$ absorption, distribution, metabolism and elimination; CYP450 = cytochrome-P450; PAMPA = parallel artificial membrane permeability assay; UGT = uridine diphospho (UDP)-glucuronosyltransferase. including evidence of tumour-infiltrating leukocytes by immunohistochemistry, and specific cellular or humoral immunity (Gajewski, 2000). It should be possible to use much smaller group sizes of 3-5 in pharmacodynamic studies in comparison to those in efficacy studies (see below). Simultaneous measurement of drug concentrations and mechanistic biomarkers is recommended to reduce animal numbers and establish a pharmacokineticpharmacodynamic relationship. Judicious application of such studies in a drug discovery test cascade should be used to prioritise agents before entry into efficacy studies.

\section{Efficacy determinations}

All relevant information should be used to guide the design of tumour efficacy studies. Such studies generally involve examination of treatment effects over a 2- to 4 -week period and establish how the therapeutic response relates to pharmacokinetic and pharmacodynamic parameters. Typically, with treatments delivered by an appropriate route of administration (Table 4), response is determined in 6-10 animals per study group ( $v s$ a control group) either by direct twice-weekly calliper measurement of superficial tumours (Kelland, 2004), counting lung or liver metastases ex vivo, or using imaging methodologies (Edinger et al, 2002; Hoffman and Yang, 2005; Brindle, 2008; McCann et al, 2009; Yang et al, 2009). Alternatively, post-treatment excision of tumours for in vitro determination of clonogenic survival, or determination of the dose required to inhibit tumour growth by $50 \%$ (tumour control dose- $\mathrm{TCD}_{50}$ ) may be appropriate (see Radiation therapy section below). Methods are available to determine sample sizes for single- and combination-agent studies and to allow for incomplete data sets (Tan et al, 2005). For certain targets, alternative, surrogate in vivo efficacy models in nontumour-bearing animals may be used, such as assessment of antioestrogenic activity by determining the effect on hypothalamic function (Kato et al, 1968).

Table 4 Maximum volumes to be administered on each occasion

\begin{tabular}{|c|c|c|}
\hline Route & Mouse & Rat \\
\hline Intra-arterial, bolus injection & NA & $0.1 \mathrm{ml}$ \\
\hline Intraperitoneal, bolus injection & $20 \mathrm{ml} \mathrm{kg}^{-\left.\right|^{a}}$ & $10 \mathrm{ml} \mathrm{kg}^{-1}$ \\
\hline Subcutaneous, bolus injection & $20 \mathrm{ml} \mathrm{kg}^{-\left.\right|^{\mathrm{ab}}}$ & $10 \mathrm{ml} \mathrm{kg}^{-1}$ \\
\hline Intradermal, bolus injection & $0.05 \mathrm{ml}$ per site ${ }^{\mathrm{b}}$ & $0.1 \mathrm{ml}$ per site \\
\hline Oral, by gavage & $\begin{array}{l}20 \mathrm{ml} \mathrm{kg}^{-1} \text {, or } 50 \mathrm{ml} \mathrm{kg}^{-1} \text { on one } \\
\text { occasion only }\end{array}$ & $\begin{array}{l}20 \mathrm{ml} \mathrm{kg}^{-1} \text {, or } 30 \mathrm{ml} \mathrm{kg}^{-1} \text { on one } \\
\text { occasion only }\end{array}$ \\
\hline Slow intravenous/arterial injection & $0.8 \mathrm{ml}$ over $2 \mathrm{~min}$ & $5 \mathrm{ml}$ over $2 \mathrm{~min}$ \\
\hline Intratumour, bolus injection & $0.1 \mathrm{ml}$ & $0.1 \mathrm{ml}$ \\
\hline
\end{tabular}

Abbreviation: NA = not applicable. The volumes used should be the minimum practicable depending on the solubility of the agent and accuracy of administration, and should be adjusted according to individual animal body weights at each dosing. Multiple administrations should typically be separated by a period of $6-8 \mathrm{~h}$. The frequency of dosing should

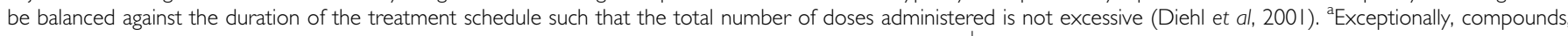
which are poorly soluble in water may be administered as a weak solution in a volume of up to $50 \mathrm{ml} \mathrm{kg}^{-1}$ in the mouse, to avoid the use of organic solvents or detergents. Additionally, $5 \%$ dextrose/saline may be injected in volumes up to $50 \mathrm{ml} \mathrm{kg}^{-1}$ for rehydration of mice after surgery. Similar increases in volume can be applied to rats. ${ }^{b}$ Maximum of two sites per animal. "Maximum rate of $2.5 \mathrm{ml} \mathrm{min}{ }^{-1}$ should be used for total infusion times $<1$ min. "Where agents need to be administered over several days or weeks, s.c. or i.p. osmotic pumps may be used, which may be left in position for up to 4 weeks. 


\section{Box 3 EXPERIMENTAL STUDY DESIGN}

I. Power analysis calculations should be applied to determine sample sizes. There are many commercially available statistical packages to support such calculations.

A number of variables need to be specified to perform the analysis. including the effect size of biological interest (specified by the experimenter), the standard deviation, the significance level (normally set to $5 \%$ ) and the desired power of the experiment. The desired power should be set to a minimum of $80 \%$ (i.e., at least an $80 \%$ chance of declaring the defined 'meaningful biological change' as being statistically significant)

Estimates of biological variability should be used in sample size and power calculations. These estimates are established from accrued historical databases, pilot studies or published data. Biological databases must be continually updated and monitored with a regular review of group sizes. It is helpful to plot the variance estimates for control groups from a given type of test with time, and constant attempts made to identify any underlying cause of variation, which may ultimately lead to a reduction in group size

2. Multiple treated groups will often be compared against one control to reduce the number of studies performed. As the control group is involved in every comparison, i.e., to all treated groups, it is often appropriate to set the control group size to be higher in comparison with the treated groups

3. When optimising animal model conditions, factorial design provides a set of tools for efficiently exploring multiple parameters simultaneously. Factorial design is a more efficient approach in comparison with the common one-variable-at-a-time approach, and leads to a more reliable understanding of the effects of parameters and their interactions. This in turn can lead to a better animal model

4. The power analysis calculation described above provides fixed sample sizes for each compound. An alternative, applicable in appropriate situations, would be to adopt a sequential design. Compounds are tested on more than one occasion and stopping rules are devised, so that extreme compounds (either highly effective or not effective at all) are dropped early from the study. The advantage to a sequential design is that on average fewer animals will be used per compound in comparison with the fixed-sample-size case

\section{Administration of experimental agents}

Various sources are available for advice on well-tolerated injection volumes and recommended administration schedules. It is important to note that, from an animal welfare point of view, frequency and duration of dosing are as important as the volume and composition of the injected solution. Some commonly used examples are given in Table 4 and the following references: Diehl et al (2001); Morton et al (2001). More frequent dosing would need to be justified by pharmacokinetic or pharmacodynamic data. As an illustration of standard procedures, for oral/i.p. or i.v. dosing in mice, volumes of 10 and $5 \mathrm{ml} \mathrm{kg}^{-1}$, respectively (equating to 200 and $100 \mu \mathrm{l}$ for a $20 \mathrm{~g}$ mouse), are widely accepted. However, the smallest volume that can be accurately and safely administered must always be used.

Where possible, compounds should be administered in an aqueous solution (sterile water for injections, $0.9 \%$ saline or $5 \%$ dextrose/saline) that is as close to physiological $\mathrm{pH}$ as possible, as highly acidic or basic solutions can be an irritant. If organic solvents (like dimethylsulphoxide, DMSO) are necessary, these should not exceed $5 \mathrm{ml} \mathrm{kg}^{-1}$ or $10 \%$ of the injected volume. Detergents (such as Tween), solubilisers or emulsifiers should not exceed $20 \%$ of the injected volume. Cyclodextrins should not exceed $2 \mathrm{ml} \mathrm{kg}^{-1}$ or $45 \%$ of the injected volume, and where used at $>20 \%$ of the injected volume, animals need to be rehydrated within $2-4 \mathrm{~h}$.

\section{Experimental design including statistics}

To maximise the scientific integrity of data generated while at the same time using the minimum number of animals, statistical

\section{Box 4 Data analysis}

I. Sometimes data need to be transformed before data analysis. The justification for transforming data should be given. A pertinent example is determining the percentage inhibition of tumour growth from comparative tumour volume data. As the variance of tumour measurements increases with the mean, data should ideally be analysed on a logarithmic scale, with each animal exhibiting a difference in $\log 10$ (tumour volume) from initial

2. Meaningful biological change, measurable endpoints and intended statistical analyses should be pre-defined. For the percentage inhibition of tumour growth example, a suitable endpoint would be a comparison of the change in tumour volume: i.e., $\log 10$ (final volume) $-\log 10$ (initial volume) between the control and the treatment groups

3. When examining changes in means in one direction only (e.g., when identifying inhibition rather than change) then one-sided (rather than two-sided) statistical tests will be used. For a comparison of two groups a $t$-test is adequate, whereas experimental data with multiple groups (vs a control) should be analysed by one-way ANOVA

Abbreviation: ANOVA = analysis of variance

expertise should be applied to all experimental design and analyses (Festing, 2002; Festing and Altman, 2002; Festing et al, 2002; see Boxes 3 and 4).

\section{Chemoprevention}

These studies routinely use either carcinogen-induced rat tumours (e.g., azoxymethane-induced colorectal cancer) or mouse genetic models of carcinogenesis (e.g., $A p c^{\text {Min }}$ colorectal; Corpet and Pierre, 2003; Cai et al, 2009). Generally, animals receive the putative chemopreventive agent in the diet or drinking water over an extended period at innocuous doses. Tumour development is measured at the end of the study and compared with animals on a relevant control diet. Relatively large numbers of rodents (e.g.; $\geqslant 14$ per group; Cai et al, 2009) may be required for the observed differences between the intervention and control groups to be robust. Mechanistic and pharmacodynamic endpoints should also be included (Yang et al, 2001; Corpet and Pierre, 2003).

\section{Radiation therapy}

External beam radiotherapy is primarily used for local tumour irradiation, which requires lead shielding to minimise normal tissue exposure. Typically, s.c. tumours are used and combination treatment with a novel therapy is tested. Endpoints include local control, growth delay and in vivo - in vitro clonogenic survival $\left(\mathrm{TCD}_{50}\right)$. Time to re-growth is preferred to a single time point analysis. Local tissue toxicity is usually manifest as skin erythema but should be minimised by restricting localised doses to less than $30 \mathrm{~Gy}$ (single dose). Exploration of better tolerated, clinically relevant fractionated doses (e.g., 2-5Gy per fraction over 1-2 weeks) is encouraged. Should moist desquamation occur, this should not be allowed to persist for more than $24 \mathrm{~h}$. Irradiated s.c. tumours can show ulceration, which may reflect tumour response. However, if there is evidence of infection and/or no signs of tissue repair the animal should be humanely killed. The acute and late effects of radiation treatment may also be examined in a relevant organ, particularly when studying new combination paradigms. A common endpoint has been the development of fibrosis in lung tissue, although more recently measurement of breathing rate has been implemented to detect symptoms before they become distressful to the animal (Jackson et al, 2010).

Radiotherapy can also be delivered in the form of targeted radionuclides (normally attached to antibodies; e.g., Martensson et al, 2005). Normal tissue toxicity will depend on antigen 
expression on tissues relative to the tumour and the nature of the emitter. Whole-body irradiation can also be used to suppress the immune response of an animal, for example, or to treat disseminated disease. Selected doses should not manifest toxicity over the duration of the experiment, for example, gut toxicity within 5 days or haematological toxicity within 30 days.

\section{UV radiation (UVR)}

The response of mouse skin to UVR may be used, for example, to study the aetiology of non-melanoma skin cancer (van Kranen and de Gruijl, 1999; Hedelund et al, 2006). Generally, experiments are performed with hairless (Skh-hr2) mice. As mouse skin does not show signs of burning, it is important to use a biologically relevant, non-burning dose of $0.2-0.3$ MED (minimal erythema dose; $50 \%$ skin thickening $=0.5 \mathrm{MED}$ ). Skin thickness should be measured $2-3$ times weekly after increasing the dose of UVR until $20-30 \%$ thickening has occurred. If hyperplasia is maintained over $12-15$ weeks skin tumours may form. A protective mouse restrainer should be used as UV radiation is damaging to eyes and ears.

\section{IMAGING}

\section{General considerations}

Imaging techniques now have a principal role in translational cancer research, enabling sequential analysis of biological endpoints in the same animal, with obvious welfare benefits. The main utility of small-animal imaging is for monitoring deep-seated tumours and metastases with or without treatment. Applications include studies of basic biological processes and of tissue pharmacokinetics and pharmacodynamic responses to treatment (Paulmurugan et al, 2002; Galbraith et al, 2003; Pillai et al, 2008; Tennant et al, 2009; Nguyen et al, 2009b). However, animal numbers may not be reduced if, for example, full endpoint analysis requires surgical intervention such as cannulation of blood vessels or when contrast agents have a long half-life. Here, sequential imaging may not be possible and alternative techniques involving tissue excision may provide more information (usually at higher spatial resolution) from the same number of animals.

There is an increasing clinical need for pharmacodynamic imaging with molecularly targeted cancer therapeutics. However, interpretation of imaging signals is often difficult and animal models have an important role in rigorous validation of new techniques. This needs to be accompanied by consideration of unique animal welfare issues. Use of external imaging techniques on small animals is not completely non-invasive as some form of anaesthesia or physical restraint is necessary and surgery or administration of contrast agents may be required.

\section{Imaging techniques}

The applications, advantages and disadvantages of commonly used imaging technologies are summarised in Table 5 and have also been reviewed recently (Workman et al, 2006; Brindle, 2008; Weissleder and Pittet, 2008). Whole-body optical imaging is relatively simple and cost-effective (Edinger et al, 2002). Tumour cells are genetically modified to constitutively or inducibly express a fluorescent protein (e.g., eGFP, dsRed) or an enzyme that activates an exogenously administered substrate to a bioluminescent molecule (usually luciferase for activation of a luciferin). The whole animal is imaged using sensitive optical detectors, which may or may not incorporate a tomographic facility (Figure 4). The potential influences of genetic modification and/or substrate administration on immunogenicity and response to treatment, as well as animal welfare, must be considered
(Tuchin, 1993; Dennis, 2002; Condeelis and Segall, 2003; Wells et al, 2006).

Intravital microscopy uses a wide variety of optical imaging techniques, often incorporating fluorescent or bioluminescent genetic reporters or markers, including nano-particles (Hoffman, 2005). It has particular animal welfare issues because it involves surgery to provide optical clarity and visualisation on a microscope stage or using fibre-optic light guides (Weissleder and Pittet, 2008). Some intravital microscopy techniques (e.g., tumours growing in the intestinal mesentery) require laparotomy with deep anaesthesia, so that imaging is only possible for a few hours under terminal anaesthesia. Surgical implantation of 'window' chambers for tumour implantation enables imaging to be performed over days to weeks (Dewhirst et al, 1987; Lehr et al, 1993; Brown et al, 2001; Reyes-Aldasoro et al, 2008). Here, general anaesthesia is only essential for the initial surgery and imaging may be performed with restrained animals. Strict aseptic technique and good post-operative care and analgesia are essential (Richardson and Flecknell, 2005; Flecknell, 2008).

Most physical imaging techniques require use of exogenous contrast agents and only positron emission tomography (PET) and single photon emission computed tomography (SPECT) are sufficiently sensitive to allow use at true tracer levels; so possible pharmacological effects of contrast agents need to be carefully considered. The same procedures for tolerability testing should apply to imaging agents as for new drugs. Some magnetic resonance imaging (MRI) techniques use inherent properties of tissues to provide endogenous imaging contrast. For instance, BOLD (blood-oxygen-level-dependent) MRI allows assessment of tissue oxygenation. These techniques avoid the use of pharmacological agents but results may be difficult to interpret.

Contrast-enhanced CT has the highest spatial resolution of all clinically applicable imaging techniques and is amenable to rapid kinetics. However, depending on the operating parameters and scan length, this may involve considerable ionising radiation dose per scan (0.02-0.6 Gy; typically 0.1-0.3 Gy) (Boone et al, 2004; Carlson et al, 2007; Brindle, 2008). Doses should be minimised to avoid compromising experimental results through interaction of ionising events with the biological processes of interest, as well as welfare issues; as a guide, total radiation dose $>1 \mathrm{~Gy}$ can affect tumour growth and whole-body doses $>6 \mathrm{~Gy}$ are generally lethal to small rodents. Users of fused PET-CT or SPECT - CT systems should note that the radiation dose from the PET or SPECT can be as large as the CT dose. In addition, iodine-based contrast agents are nephrotoxic and, if required for repeat studies, well-tolerated doses should be established.

\section{Anaesthesia and restraint for imaging}

Physical restraint and/or general anaesthesia are required for small-animal imaging. Both procedures can affect animal wellbeing and introduce experimental artefacts. Body temperature must be maintained and monitored during general anaesthesia using thermostatically controlled heating pads, microwaveable gels or warm air blowers. Light general anaesthesia using an inhalational anaesthetic such as isofluorane or a short-lived i.v. injectable such as propafol should be used for pharmacological restraint, wherever possible. Deleterious effects of physical restraint can be minimised by appropriate design of restrainers, provision of black-outs and acclimatisation (Warden et al, 2000; Narciso et al, 2003; King et al, 2005). Preferred methods will depend on the species, imaging modality and device used. Where general anaesthesia is not appropriate, sedation with use of gentle physical restraint is encouraged, taking account of veterinary advice. Acclimatisation needs to be thorough, as a short period of training can induce more stress (Warden et al, 2000; Narciso et al, 2003). 
Table 5 Examples of imaging techniques

\begin{tabular}{llll}
\hline Imaging method & Imaging time & Spatial resolution & Main purpose \\
\hline Optical: & Sec-min & $\begin{array}{l}\text { Organ: } 50 \mu \mathrm{m} \text { Whole } \\
\text { body: I }-5 \mathrm{~mm}\end{array}$ & $\begin{array}{l}\text { Monitoring tumour response } \\
\text { to treatment in deep-seated/ } \\
\text { Bioluminescence }\end{array}$ \\
and fluorescence & & $\begin{array}{l}\text { orthotopic sites and metastatic } \\
\text { spread; imaging gene } \\
\end{array}$ & \\
& & $\begin{array}{l}\text { expression and protein- } \\
\text { protein interactions }\end{array}$
\end{tabular}

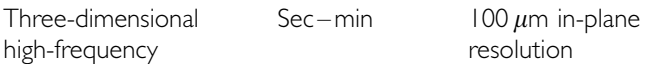

ultrasonography resolution
Relative measure of tissue blood flow; three-dimensional measurement of tumour size

or spectroscopy

imaging (MRSI)

Standard or contrastenhanced computed tomography (CT)

\section{Pharmacodynamics, pathophysiology, pharmacokinetics, anatomy resolution $(71)$; much higher for spectroscopy without imaging \\ Sec-min $\quad 100 \mu \mathrm{m}$ \\ Min-hours \\ Pharmacodynamics, anatomy}

Advantages
Relatively non-invasive
(requires restraint), high
sensitivity (amol-nmol); m
fluorescent and near-infrar
probes available; amenable
to use of gene reporters;
relatively cheap
Relatively non-invasive
(requires restraint), high
sensitivity (single particle);
absolute measurements
are possible with suitable
contrast agents, e.g..
microbubbles

Some techniques use endogenous contrast; good spatial resolution (imaging)

Very good spatial resolution combined with relatively good sensitivity

\section{Disadvantages}

In most cases, these methods require genetic modification of tumour cells for detection; quantitation relies on $2 \mathrm{D}$ images in current imaging systems; nude or shaved animals are required

Specialized application

\author{
Poor sensitivity (mmol), so \\ that exogenous contrast agents \\ and drugs need to be given \\ at high concentration \\ High radiation dose (for \\ standard CT, 2 cGy for most \\ currently available systems), \\ limited number of contrast \\ agents, which may be \\ nephrotoxic \\ available compared with PET, \\ less quantitative \\ Poor spatial resolution; full \\ quantitation requires \\ cannulation (for kinetic studies); \\ requires specialized \\ radiochemistry in most \\ situations
}

Requires surgical intervention
High sensitivity (pmol) Limited radiochemicals Radiochemistry can be performed in nuclear medicine department

High sensitivity (pmol) allowing true tracer kinetics; unlimited range of radiochemicals making it very flexible; fully quantitative

Microscopic spatial resolution good sensitivity (single cell), many fluorescent contrast agents readily available, amenable to use of gene reporters; relatively cheap

\section{Length of imaging sessions}

If applicable, animals should be transported to imaging facilities in suitable transport boxes, with food and water provided before imaging. The length, total number of imaging sessions and intervals between them depend on factors such as time required to acquire images, tolerance to restraint or general anaesthesia, half-life of the contrast agent and whether cannulation is required. Consideration also needs to be given to exposure of immunedeprived animals to a non-pathogen-free environment, as well as monitoring and control of animal physiology during imaging. If animals have no access to water, an imaging session should typically last no more than $2 \mathrm{~h}$ and total imaging time should not exceed $2-3 \mathrm{~h}$ in a 24 -h period. Use of un-anaesthetised animals restrained for more than $2 \mathrm{~h}$ must be avoided except where there is exceptional justification, for example, for animals recovering from general anaesthesia after cannulation of superficial vessels before imaging. In this case, use of local analgesia around the cannulation site is essential. Animals anaesthetised for more than $2 \mathrm{~h}$ should be rehydrated if recovery is prolonged, for example, by injection of dextrose/saline. If animals need to be anaesthetised more than once per day, they must be fully recovered, eating and drinking before being re-anaesthetised. On completion of a session, animals should either be killed or kept warm until full recovery from anaesthesia or until the next analysis session. Analysis may be repeated on the same animal but typically this should not exceed five sessions within a 1 - to 2 -week period and typically no more than one imaging session per day.

\section{HUMANE ENDPOINTS}

There are ethical, scientific and legal reasons for ensuring that adverse effects are minimised. Choice of appropriate humane endpoints provides significant opportunities for refinement, and should be developed in tandem with the requirements for a valid scientific outcome. Early endpoints reduce non-specific systemic effects and so may increase the precision of the results obtained. Pilot studies, including autopsy to determine the full extent of tumour growth, will facilitate the definition of robust and refined 
A

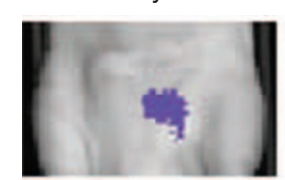

Day 8

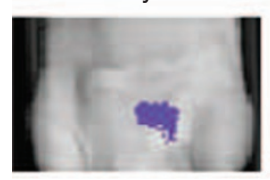

B

Transverse images

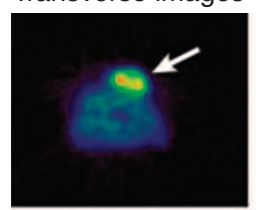

Coronal images

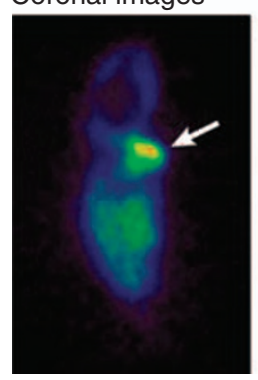

Pre-treatment
Day 15

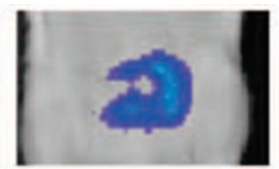

Day 15
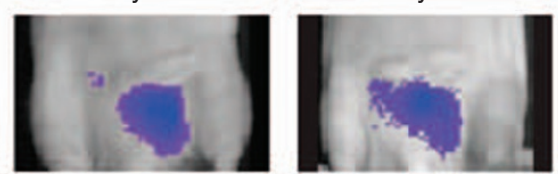

Day 29

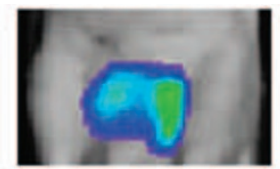

Day 29
C

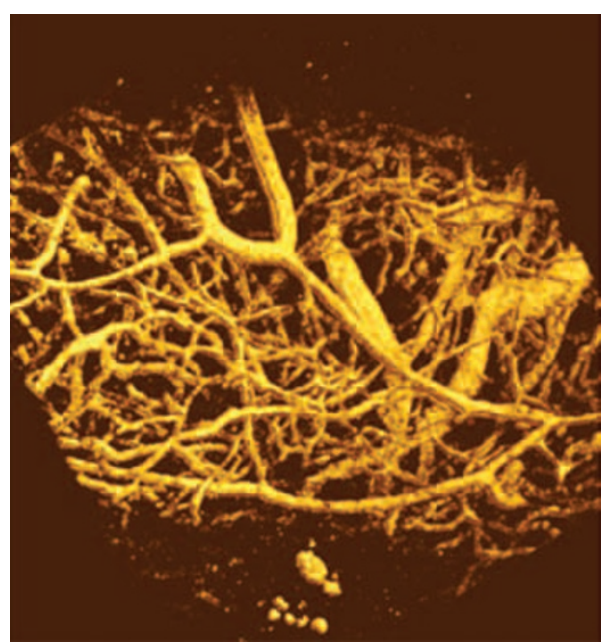

Day 41

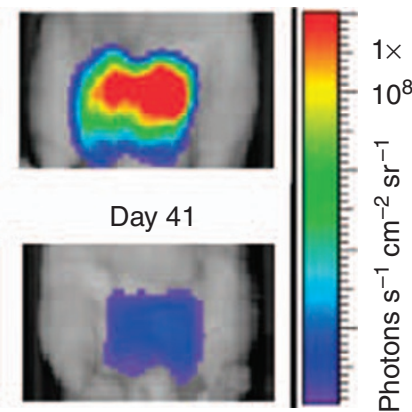

$1 \times$

ह

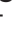

동
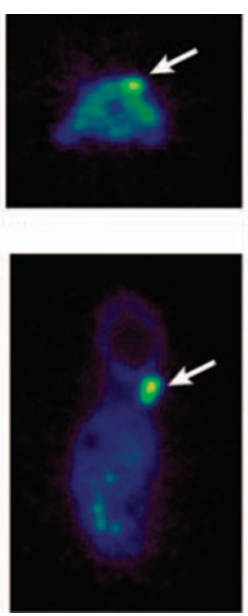

Post-treatment

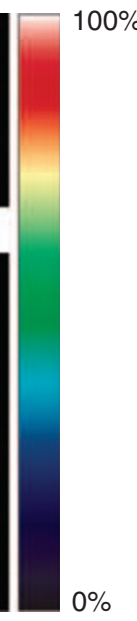

A

Figure 4 Examples of in vivo imaging in pre-clinical cancer research. (A) Optical surface bioluminescence imaging of orthotopically xenografted human PC3 prostate carcinoma cells transfected with luciferase (PC3luc2a). Mice were imaged using a Charged Coupled Device (CCD) camera, which is super-cooled to enhance detection sensitivity and image resolution. The images shown were taken after systemic administration of luciferin, with 'intensity of luminescence' shown as 'heat' maps and red as maximum intensity. The scale shows the number of photons detected. Top panel: Untreated mice at day 8-4I after transplantation; bottom panel: before and after treatment with $5 \mathrm{mg} \mathrm{kg}^{-1}$ taxotere on day 10 . This technique is useful for monitoring treatment effects in deep-seated tumour sites. Light scattering through tissues makes precise quantitation difficult. (B) PET imaging of tumour cell proliferation using ${ }^{18} \mathrm{~F}$-3'-fluoro-3'-deoxy-L-thymidine (FLT). Transverse and coronal $(0.5 \mathrm{~mm})$ images of HCTII6 tumour-bearing mice $24 \mathrm{~h}$ before treatment and after 4 daily treatments with the histone deacetylase inhibitor LAQ842 at $25 \mathrm{mg} \mathrm{kg}^{-1}$. 30- to 60-min summed images from a dynamic scan are presented. Numerous radiotracers are available for investigating specific biochemical pathways in vivo, if specialised facilities are available. The scale shows the intensity of radiotracer uptake. (C) Intravital imaging of tumour vasculature of the P22 rat sarcoma growing in a dorsal skin flap window chamber. The image was obtained by multi-photon fluorescence microscopy after i.v. administration of $70 \mathrm{kDa}$ FITC-dextran. High spatial resolution is obtained but surgical intervention is required.

endpoints. Endpoints for particular models must also take account of the known pathogenesis of the particular tumour model in question and should be regularly reviewed in the light of experience.

The endpoints proposed are based on animal models in widespread use (for examples see Tables 1 and 2); however, each study should be considered on its own merits. For example, tumorigenicity studies can be terminated as soon as progressive tumour growth is evident. By contrast, carcinogen-induced skin papillomas, for example, undergo malignant transformation late in their development and may require later endpoints. Imaging techniques facilitate the development of more defined endpoints for some tumour models. Every effort should be made to identify factors allowing scientific decisions to be made at the earliest stage possible, while taking into account the total burden of procedures on animal welfare. The intentional use of death as an endpoint is unacceptable and animals should not be allowed to become moribund.

The choice of site for solid tumours will influence the maximum acceptable tumour load and the appropriate humane endpoints. Sites such as the footpad, tail, eye or bone are likely to be painful or distressing and require special justification and earlier endpoints. Similarly, tumours that metastasise to sensitive sites need great care. If brain tumours can be justified (e.g., to increase understanding of their biology and to develop therapies for this area of unmet clinical need), body weight loss is reportedly a sensitive endpoint (Redgate et al, 1991) and MRI or bioluminescent imaging (BLI) techniques can be very useful (van Furth et al, 2003; Ragel et al, 2008; McCann et al, 2009). Intramuscular tumours are painful and only justified where there is a strong case for orthotopic studies, for example, for sarcomas.

In genetically modified animals, particular care is needed to ensure detection of unexpected sites of tumour development. As with all internal tumour sites, this includes clinical examination, measurement of body weight, abdominal palpation and loss of condition. Humane endpoints, specialist care and interventions should reflect best practice and be discussed and agreed between researchers, veterinarians and animal care staff before commencement of the experiment. Development and publication of appropriate experimental analyses (e.g., pharmacodynamic determinations, functional imaging) to capture detailed phenotypic information assists rational determination of endpoints. 


\section{Tumour burden}

Tumour burden should always be limited to the minimum required for a valid scientific outcome. For example, efficacy studies should be terminated once durable, statistically significant therapeutic effects can be shown. Therapeutic studies should be designed to avoid the need for control tumours to become excessively large. The size of any tumours should be limited when they are used simply for routine transplantation or as a source of tumour tissue. In all cases the general health and condition of an animal remains the overriding determinant. Adverse effects on the animal will depend on the biology, site, mode of growth of the tumour and any additional procedures or treatments. Despite the caveats, estimation of tumour size and burden is an important consideration in determining endpoints.

Assessment of the size of superficial tumours using callipers (usually of two diameters at right angles) is an easy and definable method. Measurement variations can be minimised by ensuring that the same well-trained technician is involved for the duration of the study. Response to therapy may be measured by changes in tumour growth rate, re-growth delay, cell survival (measured by clonogenic assay) or an appropriate surrogate marker. Excising and weighing tumours at the end of a study can provide an additional objective endpoint, which avoids errors due to variations in tumour shapes and estimations of volume or mass. For an animal carrying a single tumour, the mean diameter should not normally exceed $1.2 \mathrm{~cm}$ in mice or $2.5 \mathrm{~cm}$ in rats, or 1.5 and $2.8 \mathrm{~cm}$, respectively, for therapeutic studies. Where two tumours per animal are grown, for example, in contralateral flanks, the size should be correspondingly less and should not exceed the maximum burden of a single tumour. Multiple tumours may develop in genetically modified animals (e.g., mammary tumours in polyoma virus middle $\mathrm{T}$ transgenic mice; Guy et al, 1992) or in the skin of animals subjected to UVR (El-Abaseri and Hansen, 2007) or chemical carcinogens (Johansen et al, 2009), for which similar limits should be observed. Exceptions to these advised size limits would require rigorous scientific justification.

Determining the tumour burden of internal orthotopic cancers, systemic lymphoreticular tumours or metastatic disease is challenging. Pilot experiments using small numbers of animals are important to allow characterisation of the kinetics and patterns of spread, to predict clinical signs and to define humane endpoints. Biomarkers or circulating cancer cells may be used as surrogates for assessing the burden of lymphomas and leukaemias, and realtime imaging is a valuable adjunct. Appropriate biochemical and pathological indicators or use of engineered reporter systems or imaging techniques should be used to determine the onset of disease. Reliance must also be placed on the general condition of the animal, together with assessment of palpable tumours and specific signs such as hind-limb weakness or paralysis.

\section{Clinical signs}

In general the clinical signs shown in Box 5 are principal indicators of rare but severe symptoms of potential adverse effects, which should be avoided. Where any one sign is present the animal should immediately be humanely culled and vigilance increased for the remainder of the cohort.

With solid tumours, scoring of ulceration, distension of covering tissues and cachexia (severe body weight loss) should be incorporated into the endpoints. Ulceration is a lesion typified by necrosis of superficial tissues, which may be dry, suppurating or exudative. Necrosis resulting in skin breakdown or exudation persisting beyond $48 \mathrm{~h}$ is grounds for termination. Some tumours, such as those grown in sensitive sites or that develop extensive necrosis, may be painful, although objective criteria are lacking for mice. Further research is required to enable better assessment of pain and to assist in formulating the most appropriate endpoints.

\section{Box 5 CLINICAL SIGNS NECESSITATING IMMEDIATE INTERVENTION}

I. Failure to eat or drink over a 24- to 48-h period resulting in emaciation or dehydration

2. Consistent or rapid body weight loss reaching $20 \%$ at any time or $15 \%$ maintained for $72 \mathrm{~h}$ compared with the pre-treatment weight of adult mice or age-matched, vehicle-treated controls. With some tumours body weight is a very poor indicator and muscle atrophy or emaciation is more useful. Body condition scoring provides a very useful indication of muscle loss (Ullman-Cullere and Foltz, 1999)

3. Persistent hypothermia

4. Bloodstained or mucopurulent discharge from any orifice

5. Laboured respiration, particularly if accompanied by nasal discharge and/or cyanosis

6. Enlarged lymph nodes or spleen

7. Hind-limb paralysis or weakness

8. Anaemia as indicated by symptoms such as pale feet, or haematological measures

9. Significant abdominal distension or where ascites burden exceeds $10 \%$ of the bodyweight of age-matched controls. Accurate determination is difficult but body girth is useful and a $20 \%$ increase should be the maximum normally allowed; similar to the appearance of a pregnant mouse

10. Incontinence or diarrhoea over a 48-h period

II. Tumours that interfere with locomotion or cause abnormal vocalisation, animal behaviour or function

Such severe symptoms are likely to occur very rarely in well-designed experimental studies, should be avoided and require immediate humane termination.

In all cases endpoints must provide for action to be taken to terminate animals humanely when the degree of suffering cannot be justified by the scientific objective, when the objective has been achieved or cannot be realised, or when the quality of the results has been compromised.

\section{SUMMARY AND CONCLUDING REMARKS}

This set of guidelines is designed to update and enhance the second edition (Workman et al, 1998). Information is provided on the more complex, molecularly defined and biologically relevant models now available, including genetically engineered, orthotopic and metastatic tumour systems. These more 'patient-like' models require sophisticated methods of evaluation; hence a detailed section on the different imaging modalities that are now used has been added. Tables 1 and 2 provide examples of some widely used experimental models. Figure 1 offers an example of the type of illustrative aid that can be used to facilitate the rational choice of appropriate models in a given study. Examples of tumour models, experimental design and procedures are provided throughout. However, it is emphasised that these are intended to act as a guide only, and each study should be tailored to the specific experimental objectives. There is renewed emphasis on continuing applications of the 3Rs - replacement (of animals with alternative methods), reduction (in the numbers of animals used to achieve scientific objectives) and refinement (in experimental design, techniques and husbandry to minimise adverse effects and improve welfare). There is an expectation that the highest animal welfare standards will be demanded from grant-awarding bodies and scientific journals. It is also emphasised that there is a responsibility for researchers to publish improved models and methodology for the benefit of the research community worldwide. A comprehensive bibliography is included to cover all of the principal topics and links to other, online resources are also provided. It is to be stressed that animal welfare considerations are not only important for ethical and legal reasons, but also should be fully consistent with the highest standards of scientific investigation. It is anticipated that the appropriate use of animal models will make an important contribution to increasing further our fundamental understanding of cancer and will enhance our growing ability to diagnose, treat and prevent it. 


\section{ACKNOWLEDGEMENTS}

We thank authors Professor Fran Balkwill, Dr David Farningham, Professor Gill Tozer, Professor Sue Watson and Dr Steve Wedge for leading and coordinating subgroups of the committee dealing with specific topics.

\section{REFERENCES}

Abatan OI, Welch KB, Nemzek JA (2008) Evaluation of saphenous venipuncture and modified tail-clip blood collection in mice. $\mathrm{J} \mathrm{Am}$ Assoc Lab Anim Sci 47: 8-15

Aguirre AJ, Bardeesy N, Sinha M, Lopez L, Tuveson DA, Horner J, Redston MS, DePinho RA (2003) Activated Kras and Ink4a/Arf deficiency cooperate to produce metastatic pancreatic ductal adenocarcinoma. Genes Dev 17: $3112-3126$

Ahsan H, Aziz MH, Ahmad N (2005) Ultraviolet B exposure activates Stat3 signaling via phosphorylation at tyrosine705 in skin of SKH1 hairless mouse: a target for the management of skin cancer? Biochem Biophys Res Commun 333: $241-246$

Alsheikhly AR, Zweiri J, Walmesley AJ, Watson AJ, Christmas SE (2004) Both soluble and membrane-bound forms of Flt3 ligand enhance tumor immunity following 'suicide' gene therapy in a murine colon carcinoma model. Cancer Immunol Immunother 53: 946 - 954

Artandi SE, Chang S, Lee SL, Alson S, Gottlieb GJ, Chin L, DePinho RA (2000) Telomere dysfunction promotes non-reciprocal translocations and epithelial cancers in mice. Nature 406: 641-645

Artursson P, Palm K, Luthman K (2001) Caco-2 monolayers in experimental and theoretical predictions of drug transport. Adv Drug Deliv Rev 46: $27-43$

Baersch G, Mollers T, Hotte A, Dockhorn-Dworniczak B, Rube C, Ritter J, Jurgens H, Vormoor J (1997) Good engraftment of B-cell precursor ALL in NOD-SCID mice. Klin Padiatr 209: 178-185

Balansky RM, Ganchev G, D'Agostini F, De Flora S (2002) Effects of $\mathrm{N}$-acetylcysteine in an esophageal carcinogenesis model in rats treated with diethylnitrosamine and diethyldithiocarbamate. Int J Cancer 98: $493-497$

Banerji U, Walton M, Raynaud F, Grimshaw R, Kelland L, Valenti M, Judson I, Workman P (2005) Pharmacokinetic-pharmacodynamic relationships for the heat shock protein 90 molecular chaperone inhibitor 17-allylamino, 17-demethoxygeldanamycin in human ovarian cancer xenograft models. Clin Cancer Res 11: 7023-7032

Barfield M, Spooner N, Lad R, Parry S, Fowles S (2008) Application of dried blood spots combined with HPLC-MS/MS for the quantification of acetaminophen in toxicokinetic studies. J Chromatogr B Analyt Technol Biomed Life Sci 870: 32 - 37

Bazin R, Boucher G, Monier G, Chevrier MC, Verrette S, Broly H, Lemieux $\mathrm{R}$ (1994) Use of hu-IgG-SCID mice to evaluate the in vivo stability of human monoclonal IgG antibodies. J Immunol Methods 172: 209-217

Biotechnology and Biological Sciences Research Council; Department for Environment, Food and Rural Affairs; Medical Research Council; National Centre for the Replacement, Refinement and Reduction of Animals in Research; Natural Environment Research Council; Wellcome Trust (2008) Responsibility in the use of animals in bioscience research: expectations of the major research council and charitable funding bodies. National Centre for the Replacement, Refinement and Reduction of Animals in Research, London. http://www.nc3rs.org.uk/ downloaddoc.asp?id=719 (Accessed date 30 March 2010)

Becher OJ, Holland EC, Sausville EA, Burger AM (2006) Genetically engineered models have advantages over xenografts for preclinical studies. Cancer Res 66: 3355-3359

Becker JC, Pancook JD, Gillies SD, Mendelsohn J, Reisfeld RA (1996) Eradication of human hepatic and pulmonary melanoma metastases in SCID mice by antibody-interleukin 2 fusion proteins. Proc Natl Acad Sci USA 93: $2702-2707$

Bergers G, Javaherian K, Lo KM, Folkman J, Hanahan D (1999) Effects of angiogenesis inhibitors on multistage carcinogenesis in mice. Science 284: $808-812$

Bignell GR, Greenman CD, Davies H, Butler AP, Edkins S, Andrews JM, Buck G, Chen L, Beare D, Latimer C, Widaa S, Hinton J, Fahey C, Fu B, Swamy S, Dalgliesh GL, Teh BT, Deloukas P, Yang F, Campbell PJ,
We thank Dr Robert J Shaw (Discovery Statistics, AstraZeneca, Alderley Park) for statistical input. We are also grateful to Professor Andy Gescher (University of Leicester, UK) for expert advice and a number of other individuals who kindly gave advice on specific issues or commented on previous drafts of the guidelines. We thank Dr Ben Onwuegbusi (Cancer Research UK) for help in acting as Committee Secretary.

Futreal PA, Stratton MR (2010) Signatures of mutation and selection in the cancer genome. Nature 463: 893-898

Blouin S, Basle MF, Chappard D (2008) Interactions between microenvironment and cancer cells in two animal models of bone metastasis. Br J Cancer 98: 809-815

Boone JM, Velazquez O, Cherry SR (2004) Small-animal X-ray dose from micro-CT. Mol Imaging 3: 149-158

Brindle K (2008) New approaches for imaging tumour responses to treatment. Nat Rev Cancer 8: $94-107$

Brown EB, Campbell RB, Tsuzuki Y, Xu L, Carmeliet P, Fukumura D, Jain RK (2001) In vivo measurement of gene expression, angiogenesis and physiological function in tumors using multiphoton laser scanning microscopy. Nat Med 7: 864-868

Bruneau P, McElroy NR (2006) logD7.4 modeling using Bayesian Regularized Neural Networks. Assessment and correction of the errors of prediction. J Chem Inf Model 46: 1379-1387

Bruns CJ, Harbison MT, Kuniyasu H, Eue I, Fidler IJ (1999) In vivo selection and characterization of metastatic variants from human pancreatic adenocarcinoma by using orthotopic implantation in nude mice. Neoplasia 1: 50-62

Cai H, Sale S, Schmid R, Britton RG, Brown K, Steward WP, Gescher AJ (2009) Flavones as colorectal cancer chemopreventive agents - phenol-omethylation enhances efficacy. Cancer Prev Res (Phila PA) 2: $743-750$

Carlson SK, Classic KL, Bender CE, Russell SJ (2007) Small animal absorbed radiation dose from serial micro-computed tomography imaging. Mol Imaging Biol 9: 78-82

Chan R, Muller WJ, Siegel PM (1999) Oncogenic activating mutations in the neu/erbB-2 oncogene are involved in the induction of mammary tumors. Ann N Y Acad Sci 889: 45 - 51

Chen D, Livne-bar I, Vanderluit JL, Slack RS, Agochiya M, Bremner R (2004) Cell-specific effects of RB or RB/p107 loss on retinal development implicate an intrinsically death-resistant cell-of-origin in retinoblastoma. Cancer Cell 5: 539-551

Chen X, Yang G, Ding WY, Bondoc F, Curtis SK, Yang CS (1999) An esophagogastroduodenal anastomosis model for esophageal adenocarcinogenesis in rats and enhancement by iron overload. Carcinogenesis 20: 1801-1808

Chou TC (2006) Theoretical basis, experimental design, and computerized simulation of synergism and antagonism in drug combination studies. Pharmacol Rev 58: 621-681

Christophorou MA, Martin-Zanca D, Soucek L, Lawlor ER, Brown-Swigart L, Verschuren EW, Evan GI (2005) Temporal dissection of p53 function in vitro and in vivo. Nat Genet 37: 718-726

Christophorou MA, Ringshausen I, Finch AJ, Swigart LB, Evan GI (2006) The pathological response to DNA damage does not contribute to p53-mediated tumour suppression. Nature 443: 214-217

Colclough N, Hunter A, Kenny PW, Kittlety RS, Lobedan L, Tam KY, Timms MA (2008) High throughput solubility determination with application to selection of compounds for fragment screening. Bioorg Med Chem 16: 6611-6616

Collado B, Carmena MJ, Clemente C, Prieto JC, Bajo AM (2007) Vasoactive intestinal peptide enhances growth and angiogenesis of human experimental prostate cancer in a xenograft model. Peptides 28: 1896-1901

Collins I, Workman P (2006) New approaches to molecular cancer therapeutics. Nat Chem Biol 2: $689-700$

Comstock KE, Hall CL, Daignault S, Mandlebaum SA, Yu C, Keller ET (2009) A bioluminescent orthotopic mouse model of human osteosarcoma that allows sensitive and rapid evaluation of new therapeutic agents in vivo. In Vivo 23: $661-668$

Condeelis J, Segall JE (2003) Intravital imaging of cell movement in tumours. Nat Rev Cancer 3: 921 - 930

Corpet DE, Pierre F (2003) Point: from animal models to prevention of colon cancer. Systematic review of chemoprevention in min mice 
and choice of the model system. Cancer Epidemiol Biomarkers Prev 12: $391-400$

De Fabo EC (2006) Initial studies on an in vivo action spectrum for melanoma induction. Prog Biophys Mol Biol 92: 97-104

Decker S, Hollingshead M, Bonomi CA, Carter JP, Sausville EA (2004) The hollow fibre model in cancer drug screening: the NCI experience. Eur J Cancer 40: 821 -826

Dennis C (2006) Cancer: off by a whisker. Nature 17: 739-741

Dennis Jr MB (2002) Welfare issues of genetically modified animals. Ilar J 43: $100-109$

Dewhirst MW, Gustafson C, Gross JF, Tso CY (1987) Temporal effects of $5.0 \mathrm{~Gy}$ radiation in healing subcutaneous microvasculature of a dorsal flap window chamber. Radiat Res 112: 581-591

Dickson PV, Hamner B, Ng CY, Hall MM, Zhou J, Hargrove PW, McCarville MB, Davidoff AM (2007) In vivo bioluminescence imaging for early detection and monitoring of disease progression in a murine model of neuroblastoma. J Pediatr Surg 42: 1172-1179

Diehl KH, Hull R, Morton D, Pfister R, Rabemampianina Y, Smith D, Vidal JM, van de Vorstenbosch C (2001) A good practice guide to the administration of substances and removal of blood, including routes and volumes. J Appl Toxicol 21: 15-23

Dohta Y, Yamashita T, Horiike S, Nakamura T, Fukami T (2007) A system for $\operatorname{LogD}$ screening of 96-well plates using a water-plug aspiration/ injection method combined with high-performance liquid chromatography-mass spectrometry. Anal Chem 79: $8312-8315$

Dong X, Guan J, English JC, Flint J, Yee J, Evans K, Murray N, Macaulay C, Ng RT, Gout PW, Lam WL, Laskin J, Ling V, Lam S, Wang Y (2010) Patient-derived first generation xenografts of non-small cell lung cancers: promising tools for predicting drug responses for personalized chemotherapy. Clin Cancer Res 16: $1442-1451$

Du-Cuny L, Huwyler J, Wiese M, Kansy M (2008) Computational aqueous solubility prediction for drug-like compounds in congeneric series. Eur J Med Chem 43: 501-512

Edinger M, Cao YA, Hornig YS, Jenkins DE, Verneris MR, Bachmann MH, Negrin RS, Contag CH (2002) Advancing animal models of neoplasia through in vivo bioluminescence imaging. Eur J Cancer 38: 2128-2136

El-Abaseri TB, Hansen LA (2007) EGFR activation and ultraviolet lightinduced skin carcinogenesis. J Biomed Biotechnol 2007: 97939

Felsher DW, Bishop JM (1999) Reversible tumorigenesis by MYC in hematopoietic lineages. Mol Cell 4: 199-207

Festing M, Overend P, Gaine Das R, Cortina Borja M, Berdoy M (2002) The design of Animal Experiments: Reducing the Use of Animals in Research Through Better Experimental Design. Royal Society of Medicine Press: London

Festing MF (2002) The design and statistical analysis of animal experiments. ILAR J 43: $191-193$

Festing MF, Altman DG (2002) Guidelines for the design and statistical analysis of experiments using laboratory animals. ILAR J 43: 244-258

Flecknell P (2008) Analgesia from a veterinary perspective. Br J Anaesth 101: $121-124$

Fluck MM, Haslam SZ (1996) Mammary tumors induced by polyomavirus. Breast Cancer Res Treat 39: 45-56

Freireich EJ, Gehan EA, Rall DP, Schmidt LH, Skipper HE (1966) Quantitative comparison of toxicity of anticancer agents in mouse, rat, hamster, dog, monkey, and man. Cancer Chemother Rep 50: 219-244

Frese KK, Tuveson DA (2007) Maximizing mouse cancer models. Nat Rev Cancer 7: 645-658

Gajewski TF (2000) Monitoring specific T-cell responses to melanoma vaccines: ELISPOT, tetramers, and beyond. Clin Diagn Lab Immunol 7: $141-144$

Galbraith SM, Maxwell RJ, Lodge MA, Tozer GM, Wilson J, Taylor NJ, Stirling JJ, Sena L, Padhani AR, Rustin GJ (2003) Combretastatin A4 phosphate has tumor antivascular activity in rat and man as demonstrated by dynamic magnetic resonance imaging. J Clin Oncol 21: 2831 - 2842

Garber K (2006) Realistic rodents? Debate grows over new mouse models of cancer. I Natl Cancer Inst 98: 1176-1178

Giovannini M, Robanus-Maandag E, van der Valk M, Niwa-Kawakita M, Abramowski V, Goutebroze L, Woodruff JM, Berns A, Thomas G (2000) Conditional biallelic Nf2 mutation in the mouse promotes manifestations of human neurofibromatosis type 2. Genes Dev 14: 1617-1630

Giver CR, Li JM, Hossain MS, Lonial S, Waller EK (2004) Reconstructing immunity after allogeneic transplantation. Immunol Res 29: 269-282

Glass B, Uharek L, Zeis M, Loeffler H, Mueller-Ruchholtz W, Gassmann W (1996) Graft-versus-leukaemia activity can be predicted by natural cytotoxicity against leukaemia cells. Br J Haematol 93: 412-420
Glinskii AB, Smith BA, Jiang P, Li X-M, Yang M, Hoffman RM, Glinsky GV (2003) Viable circulating metastatic cells produced in orthotopic but not ectopic prostate cancer models. Cancer Res 63: 4239-4243

Golay J, Cittera E, Di Gaetano N, Manganini M, Mosca M, Nebuloni M, van Rooijen N, Vago L, Introna M (2006) The role of complement in the therapeutic activity of rituximab in a murine B lymphoma model homing in lymph nodes. Haematologica 91: 176-183

Graf MR, Sauer JT, Merchant RE (2005) Tumor infiltration by myeloid suppressor cells in response to $\mathrm{T}$ cell activation in rat gliomas. J Neurooncol 73: 29-36

Graff BA, Benjaminsen IC, Melas EA, Brurberg KG, Rofstad EK (2005) Changes in intratumor heterogeneity in blood perfusion in intradermal human melanoma xenografts during tumor growth assessed by DCE-MRI. Magn Reson Imaging 23: 961 - 966

Guy CT, Cardiff RD, Muller WJ (1992) Induction of mammary tumors by expression of polyomavirus middle $\mathrm{T}$ oncogene: a transgenic mouse model for metastatic disease. Mol Cell Biol 12: 954-961

Ha WS, Kim CK, Song SH, Kang CB (2001) Study on mechanism of multistep hepatotumorigenesis in rat: development of hepatotumorigenesis. J Vet Sci 2: 53-58

Han Y, Chen XP, Huang ZY, Zhu H (2005) Nude mice multi-drug resistance model of orthotopic transplantation of liver neoplasm and Tc-99m MIBI SPECT on p-glycoprotein. World J Gastroenterol 11: 3335-3338

Hanahan D, Weinberg RA (2000) The hallmarks of cancer. Cell 100: 57-70

Harlin H, Gajewski TF (2008) Diagnosis and treatment of mycoplasmacontaminated cell cultures. Curr Protoc Cytom Appendix 3: Appendix 3C

Harris JC, Gilliam AD, McKenzie AJ, Evans SA, Grabowska AM, Clarke PA, McWilliams DF, Watson SA (2004) The biological and therapeutic importance of gastrin gene expression in pancreatic adenocarcinomas. Cancer Res 64: $5624-5631$

Hawariah A, Stanslas J (1998) Antagonistic effects of styrylpyrone derivative (SPD) on 7,12-dimethylbenzanthracene-induced rat mammary tumors. In Vivo 12: $403-410$

Hedelund L, Lerche C, Wulf HC, Haedersdal M (2006) Carcinogenesis related to intense pulsed light and UV exposure: an experimental animal study. Lasers Med Sci 21: 198-201

Hingorani SR, Wang L, Multani AS, Combs C, Deramaudt TB, Hruban RH, Rustgi AK, Chang S, Tuveson DA (2005) Trp53R172H and KrasG12D cooperate to promote chromosomal instability and widely metastatic pancreatic ductal adenocarcinoma in mice. Cancer Cell 7: 469-483

Hirayama T, Honda A, Matsuzaki Y, Miyazaki T, Ikegami T, Doy M, Xu G, Lea M, Salen G (2006) Hypercholesterolemia in rats with hepatomas: increased oxysterols accelerate efflux but do not inhibit biosynthesis of cholesterol. Hepatology 44: 602-611

Hirose Y, Hata K, Kuno T, Yoshida K, Sakata K, Yamada Y, Tanaka T, Reddy BS, Mori H (2004) Enhancement of development of azoxymethane-induced colonic premalignant lesions in $\mathrm{C} 57 \mathrm{BL} / \mathrm{KsJ}-\mathrm{db} / \mathrm{db}$ mice. Carcinogenesis 25: 821-825

Hoffman RM (2005) The multiple uses of fluorescent proteins to visualize cancer in vivo. Nat Rev Cancer 5: 796-806

Hoffman RM, Yang M (2005) Dual-color, whole-body imaging in mice. Nat Biotechnol 23: 790; author reply 791

Houston JB, Carlile DJ (1997) Prediction of hepatic clearance from microsomes, hepatocytes, and liver slices. Drug Metab Rev 29: 891-922

Howard ML, Hill JJ, Galluppi GR, McLean MA (2010) Plasma protein binding in drug discovery and development. Comb Chem High Throughput Screen 13: $170-187$

Huxham LA, Kyle AH, Baker JH, Nykilchuk LK, Minchinton AI (2004) Microregional effects of gemcitabine in HCT-116 xenografts. Cancer Res 64: $6537-6541$

Ihle NT, Lemos Jr R, Wipf P, Yacoub A, Mitchell C, Siwak D, Mills GB, Dent P, Kirkpatrick DL, Powis G (2009) Mutations in the phosphatidylinositol-3-kinase pathway predict for antitumor activity of the inhibitor PX-866 whereas oncogenic Ras is a dominant predictor for resistance. Cancer Res 69: 143-150

Ishikawa Y, Kozakai T, Morita H, Saida K, Oka S, Masuo Y (2006) Rapid detection of mycoplasma contamination in cell cultures using SYBR Green-based realtime polymerase chain reaction. In Vitro Cell Dev Biol Anim 42: 63-69

Jackson IL, Vujaskovic Z, Down JD (2010) Revisiting strain-related differences in radiation sensitivity of the mouse lung: recognizing and avoiding the confounding effects of pleural effusions. Radiat Res 173: $10-20$

Johansen C, Vestergaard C, Kragballe K, Kollias G, Gaestel M, Iversen L (2009) MK2 regulates the early stages of skin tumor promotion. Carcinogenesis 30: $2100-2108$ 
Johnson L, Mercer K, Greenbaum D, Bronson RT, Crowley D, Tuveson DA, Jacks T (2001) Somatic activation of the K-ras oncogene causes early onset lung cancer in mice. Nature 410: $1111-1116$

Jonkers J, Meuwissen R, van der Gulden H, Peterse H, van der Valk M, Berns A (2001) Synergistic tumor suppressor activity of BRCA2 and p53 in a conditional mouse model for breast cancer. Nat Genet 29: $418-425$

Karnoub AE, Dash AB, Vo AP, Sullivan A, Brooks MW, Bell GW, Richardson AL, Polyak K, Tubo R, Weinberg RA (2007) Mesenchymal stem cells within tumour stroma promote breast cancer metastasis. Nature 449: $557-563$

Kato J, Kobayashi T, Villec CA (1968) Effect of clomiphene on the uptake of estradiol by the anterior hypothalamus and hypophysis. Endocrinology 82: $1049-1052$

Kelland LR (2004) Of mice and men: values and liabilities of the athymic nude mouse model in anticancer drug development. Eur J Cancer 40: $827-836$

Kenerson H, Dundon TA, Yeung RS (2005) Effects of rapamycin in the Eker rat model of tuberous sclerosis complex. Pediatr Res 57: 67-75

Kennel SJ, Boll R, Stabin M, Schuller HM, Mirzadeh S (1999) Radioimmunotherapy of micrometastases in lung with vascular targeted $213 \mathrm{Bi}$. Br J Cancer 80: 175 - 184

Kim EJ, Shin M, Park H, Hong JE, Shin HK, Kim J, Kwon DY, Park JH (2009) Oral administration of 3,3'-diindolylmethane inhibits lung metastasis of $4 \mathrm{~T} 1$ murine mammary carcinoma cells in BALB/c mice. J Nutr 139: 2373 - 2379

King JA, Garelick TS, Brevard ME, Chen W, Messenger TL, Duong TQ, Ferris CF (2005) Procedure for minimizing stress for fMRI studies in conscious rats. J Neurosci Methods 148: $154-160$

Koehl GE, Gaumann A, Geissler EK (2009) Intravital microscopy of tumor angiogenesis and regression in the dorsal skin fold chamber: mechanistic insights and preclinical testing of therapeutic strategies. Clin Exp Metastasis 26: $329-344$

Komatsubara H, Umeda M, Ojima Y, Minamikawa T, Komori T (2005) Detection of cancer cells in the peripheral blood and lung of mice after transplantation of human adenoid cystic carcinoma. Kobe J Med Sci 51: 67-72

Kragh M, Hjarnaa PJ, Bramm E, Kristjansen PE, Rygaard J, Binderup L (2003) In vivo chamber angiogenesis assay: an optimized Matrigel plug assay for fast assessment of antiangiogenic activity. Int J Oncol 22: 305-311

Krimpenfort P, Quon KC, Mooi WJ, Loonstra A, Berns A (2001) Loss of p16Ink4a confers susceptibility to metastatic melanoma in mice. Nature 413: $83-86$

Lacroix M (2008) Persistent use of 'false' cell lines. Int J Cancer 122: $1-4$

Lee PH, Ayyampalayam SN, Carreira LA, Shalaeva M, Bhattachar S, Coselmon R, Poole S, Gifford E, Lombardo F (2007) In silico prediction of ionization constants of drugs. Mol Pharm 4: 498-512

Lehr HA, Leunig M, Menger MD, Nolte D, Messmer K (1993) Dorsal skinfold chamber technique for intravital microscopy in nude mice. $A m J$ Pathol 143: $1055-1062$

Li M, Huang X, Zhu Z, Wong M, Watkins S, Zhao Q, Herberman R, Gorelik $\mathrm{E}$ (2001) Immune response against 3LL Lewis lung carcinoma potentiates the therapeutic efficacy of endostatin. J Immunother 24: 472-481

Li Z, Chen Z, Lu J, Cen J, He J, Chen S, Xue Y, Guo L (2006) Establishment of a nude mice model of human monocytic leukemia with CNS and multiorgan extramedullary infiltration. Eur J Haematol 77: 128-133

Liem NL, Papa RA, Milross CG, Schmid MA, Tajbakhsh M, Choi S, Ramirez CD, Rice AM, Haber M, Norris MD, MacKenzie KL, Lock RB (2004) Characterization of childhood acute lymphoblastic leukemia xenograft models for the preclinical evaluation of new therapies. Blood 103: 3905-3914

Lifsted T, Le Voyer T, Williams M, Muller W, Klein-Szanto A, Buetow KH, Hunter KW (1998) Identification of inbred mouse strains harboring genetic modifiers of mammary tumor age of onset and metastatic progression. Int J Cancer 77: 640-644

Lock RB, Liem NL, Papa RA (2005) Preclinical testing of antileukemic drugs using an in vivo model of systemic disease. Methods Mol Med 111: 323 - 334

Mahteme H, Lovqvist A, Graf W, Lundqvist H, Carlsson J, Sundin A (1998) Adjuvant 131I-anti-CEA-antibody radioimmunotherapy inhibits the development of experimental colonic carcinoma liver metastases. Anticancer Res 18: $843-848$

Mannhold R, Poda GI, Ostermann C, Tetko IV (2009) Calculation of molecular lipophilicity: state-of-the-art and comparison of log P methods on more than 96,000 compounds. J Pharm Sci 98: $861-893$

Marcotte R, Muller WJ (2008) Signal transduction in transgenic mouse models of human breast cancer - implications for human breast cancer. J Mammary Gland Biol Neoplasia 13: $323-335$
Martensson L, Wang Z, Nilsson R, Ohlsson T, Senter P, Sjogren HO, Strand SE, Tennvall J (2005) Determining maximal tolerable dose of the monoclonal antibody BR96 labeled with $90 \mathrm{Y}$ or $177 \mathrm{Lu}$ in rats: establishment of a syngeneic tumor model to evaluate means to improve radioimmunotherapy. Clin Cancer Res 11: 7104s-7108s

Martinsen TC, Kawase S, Hakanson R, Torp SH, Fossmark R, Qvigstad G, Sandvik AK, Waldum HL (2003) Spontaneous ECL cell carcinomas in cotton rats: natural course and prevention by a gastrin receptor antagonist. Carcinogenesis 24: $1887-1896$

Masimirembwa CM, Thompson R, Andersson TB (2001) In vitro high throughput screening of compounds for favorable metabolic properties in drug discovery. Comb Chem High Throughput Screen 4: $245-263$

Masters JR et al (2001) Short tandem repeat profiling provides an international reference standard for human cell lines. Proc Natl Acad Sci USA 98: $8012-8017$

McCann CM, Waterman P, Figueiredo JL, Aikawa E, Weissleder R, Chen JW (2009) Combined magnetic resonance and fluorescence imaging of the living mouse brain reveals glioma response to chemotherapy. Neuroimage 45: $360-369$

Mitra SK, Lim ST, Chi A, Schlaepfer DD (2006) Intrinsic focal adhesion kinase activity controls orthotopic breast carcinoma metastasis via the regulation of urokinase plasminogen activator expression in a syngeneic tumor model. Oncogene 25: 4429-4440

Miyazaki K, Koshikawa N, Hasegawa S, Momiyama N, Nagashima Y, Moriyama K, Ichikawa Y, Ishikawa T, Mitsuhashi M, Shimada H (1999) Matrilysin as a target for chemotherapy for colon cancer: use of antisense oligonucleotides as antimetastatic agents. Cancer Chemother Pharmacol 43Suppl: S52-S55

Morton DB, Jennings M, Buckwell A, Ewbank R, Godfrey C, Holgate B, Inglis I, James R, Page C, Sharman I, Verschoyle R, Westall L, Wilson AB (2001) Refining procedures for the administration of substances. Report of the BVAAWF/FRAME/RSPCA/UFAW Joint Working Group on Refinement. British Veterinary Association Animal Welfare Foundation/Fund for the Replacement of Animals in Medical Experiments/Royal Society for the Prevention of Cruelty to Animals/Universities Federation for Animal Welfare. Lab Anim 35: 1-41

Nakai M, Mundy GR, Williams PJ, Boyce B, Yoneda T (1992) A synthetic antagonist to laminin inhibits the formation of osteolytic metastases by human melanoma cells in nude mice. Cancer Res 52: 5395-5399

Nakatsugawa S, Okuda T, Muramoto H, Koyama K, Ishigaki T, Tsuruoka T, Hosokawa M, Kobayashi H (1999) Inhibitory effect of ND2001 on spontaneous multiple metastasis of NC 65 tumors derived from human renal cancer cells intradermally transplanted into nude mice. Anticancer Drugs 10: $229-233$

Narciso SP, Nadziejko E, Chen LC, Gordon T, Nadziejko C (2003) Adaptation to stress induced by restraining rats and mice in nose-only inhalation holders. Inhal Toxicol 15: 1133-1143

Nardone RM (2007) Eradication of cross-contaminated cell lines: a call for action. Cell Biol Toxicol 23: $367-372$

Neale G, Su X, Morton CL, Phelps D, Gorlick R, Lock RB, Reynolds CP, Maris JM, Friedman HS, Dome J, Khoury J, Triche TJ, Seeger RC, Gilbertson R, Khan J, Smith MA, Houghton PJ (2008) Molecular characterization of the pediatric preclinical testing panel. Clin Cancer Res 14: $4572-4583$

Nguyen DX, Bos PD, Massague J (2009a) Metastasis: from dissemination to organ-specific colonization. Nat Rev Cancer 9: 274-284

Nguyen QD, Smith G, Glaser M, Perumal M, Arstad E, Aboagye EO (2009b) Positron emission tomography imaging of drug-induced tumor apoptosis with a caspase-3/7 specific [18F]-labeled isatin sulfonamide. Proc Natl Acad Sci USA 106: 16375-16380

Nijmeijer BA, Mollevanger P, van Zelderen-Bhola SL, Kluin-Nelemans HC, Willemze R, Falkenburg JH (2001) Monitoring of engraftment and progression of acute lymphoblastic leukemia in individual NOD/SCID mice. Exp Hematol 29: $322-329$

Noel A, De Pauw-Gillet MC, Purnell G, Nusgens B, Lapiere CM, Foidart JM (1993) Enhancement of tumorigenicity of human breast adenocarcinoma cells in nude mice by Matrigel and fibroblasts. Br J Cancer 68: 909-915

Nordsmark M, Maxwell RJ, Wood PJ, Stratford IJ, Adams GE, Overgaard J, Horsman MR (1996) Effect of hydralazine in spontaneous tumours assessed by oxygen electrodes and 31P-magnetic resonance spectroscopy. Br J Cancer Suppl 27: S232-S235

Orimo A, Gupta PB, Sgroi DC, Arenzana-Seisdedos F, Delaunay T, Naeem R, Carey VJ, Richardson AL, Weinberg RA (2005) Stromal fibroblasts present in invasive human breast carcinomas promote tumor growth 
and angiogenesis through elevated SDF-1/CXCL12 secretion. Cell 121: $335-348$

Osborne NJ, Payne D, Newman ML (2009) Journal editorial policies, animal welfare, and the 3Rs. Am J Bioeth 9: 55-59

Ottaviani G, Martel S, Carrupt PA (2006) Parallel artificial membrane permeability assay: a new membrane for the fast prediction of passive human skin permeability. J Med Chem 49: $3948-3954$

Park ES, Rabinovsky R, Carey M, Hennessy BT, Agarwal R, Liu W, Ju Z, Deng W, Lu Y, Woo HG, Kim SB, Cheong JH, Garraway LA, Weinstein JN, Mills GB, Lee JS, Davies MA (2010) Integrative analysis of proteomic signatures, mutations, drug responsiveness in the NCI 60 cancer cell line set. Mol Cancer Ther 9: 257-267

Parodi B, Aresu O, Bini D, Lorenzini R, Schena F, Visconti P, Cesaro M, Ferrera D, Andreotti V, Ruzzon T (2002) Species identification and confirmation of human and animal cell lines: a PCR-based method. Biotechniques 32: 432 -434, 436, 438-40

Patel S, Turner PR, Stubberfield C, Barry E, Rohlff CR, Stamps A, McKenzie E, Young K, Tyson K, Terrett J, Box G, Eccles S, Page MJ (2002) Hyaluronidase gene profiling and role of hyal-1 overexpression in an orthotopic model of prostate cancer. Int J Cancer 97: 416-424

Paulmurugan R, Umezawa Y, Gambhir SS (2002) Noninvasive imaging of protein - protein interactions in living subjects by using reporter protein complementation and reconstitution strategies. Proc Natl Acad Sci USA 99: $15608-15613$

Pearse G, Frith J, Randall KJ, Klinowska T (2009) Urinary retention and cystitis associated with subcutaneous estradiol pellets in female nude mice. Toxicol Pathol 37: 227-234

Pelengaris S, Littlewood T, Khan M, Elia G, Evan G (1999) Reversible activation of c-Myc in skin: induction of a complex neoplastic phenotype by a single oncogenic lesion. Mol Cell 3: 565-577

Pillai RG, Forster M, Perumal M, Mitchell F, Leyton J, Aibgirhio FI, Golovko O, Jackman AL, Aboagye EO (2008) Imaging pharmacodynamics of the alpha-folate receptor-targeted thymidylate synthase inhibitor BGC 945. Cancer Res 68: 3827-3834

Politi K, Fan PD, Shen R, Zakowski M, Varmus H (2010) Erlotinib resistance in mouse models of epidermal growth factor receptor-induced lung adenocarcinoma. Dis Model Mech 3: 111-119

Politi K, Zakowski MF, Fan PD, Schonfeld EA, Pao W, Varmus HE (2006) Lung adenocarcinomas induced in mice by mutant EGF receptors found in human lung cancers respond to a tyrosine kinase inhibitor or to downregulation of the receptors. Genes Dev 20: 1496-1510

Poller B, Gutmann H, Krahenbuhl S, Weksler B, Romero I, Couraud PO, Tuffin G, Drewe J, Huwyler J (2008) The human brain endothelial cell line hCMEC/D3 as a human blood-brain barrier model for drug transport studies. J Neurochem 107: 1358-1368

Prigozhina TB, Gurevitch O, Morecki S, Yakovlev E, Elkin G, Slavin S (2002) Nonmyeloablative allogeneic bone marrow transplantation as immunotherapy for hematologic malignancies and metastatic solid tumors in preclinical models. Exp Hematol 30: 89-96

Qian CN, Furge KA, Knol J, Huang D, Chen J, Dykema KJ, Kort EJ, Massie A, Khoo SK, Vanden Beldt K, Resau JH, Anema J, Kahnoski RJ, Morreau H, Camparo P, Comperat E, Sibony M, Denoux Y, Molinie V, Vieillefond A, Eng C, Williams BO, Teh BT (2009) Activation of the Pl3K/AKT pathway induces urothelial carcinoma of the renal pelvis: identification in human tumors and confirmation in animal models. Cancer Res 69: 8256-8264

Quaglino E, Mastini C, Forni G, Cavallo F (2008) ErbB2 transgenic mice: a tool for investigation of the immune prevention and treatment of mammary carcinomas. Curr Protoc Immunol Chapter 20: Unit 2091 Unit $209-10$

Radaelli E, Ceruti R, Patton V, Russo M, Degrassi A, Croci V, Caprera F, Stortini G, Scanziani E, Pesenti E, Alzani R (2009) Immunohistopathological and neuroimaging characterization of murine orthotopic xenograft models of glioblastoma multiforme recapitulating the most salient features of human disease. Histol Histopathol 24: 879-891

Ragel BT, Elam IL, Gillespie DL, Flynn JR, Kelly DA, Mabey D, Feng H, Couldwell WT, Jensen RL (2008) A novel model of intracranial meningioma in mice using luciferase-expressing meningioma cells. Laboratory investigation. J Neurosurg 108: $304-310$

Redgate ES, Deutsch M, Boggs SS (1991) Time of death of CNS tumorbearing rats can be reliably predicted by body weight-loss patterns. Lab Anim Sci 41: 269-273

Reilly KM, Loisel DA, Bronson RT, McLaughlin ME, Jacks T (2000) $\mathrm{Nf} 1 ; \operatorname{Trp} 53$ mutant mice develop glioblastoma with evidence of strainspecific effects. Nat Genet 26: 109-113
Reyes-Aldasoro CC, Wilson I, Prise VE, Barber PR, Ameer-Beg M, Vojnovic B, Cunningham VJ, Tozer GM (2008) Estimation of apparent tumor vascular permeability from multiphoton fluorescence microscopic images of P22 rat sarcomas in vivo. Microcirculation 15: 65-79

Richardson CA, Flecknell PA (2005) Anaesthesia and post-operative analgesia following experimental surgery in laboratory rodents: are we making progress? Altern Lab Anim 33: 119-127

Riley RJ, Martin IJ, Cooper AE (2002) The influence of DMPK as an integrated partner in modern drug discovery. Curr Drug Metab 3: $527-550$

Robanus-Maandag E, Dekker M, van der Valk M, Carrozza ML, Jeanny JC, Dannenberg JH, Berns A, te Riele H (1998) p107 is a suppressor of retinoblastoma development in pRb-deficient mice. Genes Dev 12: $1599-1609$

Rodriguez-Cuesta J, Vidal-Vanaclocha F, Mendoza L, Valcarcel M, Gallot N, Martinez de Tejada G (2005) Effect of asymptomatic natural infections due to common mouse pathogens on the metastatic progression of B16 murine melanoma in C57BL/6 mice. Clin Exp Metastasis 22: 549-558

Rottenberg S, Jonkers J (2008) Modeling therapy resistance in genetically engineered mouse cancer models. Drug Resist Updat 11: 51-60

Roughan JV, Flecknell PA, Davies BR (2004) Behavioural assessment of the effects of tumour growth in rats and the influence of the analgesics carprofen and meloxicam. Lab Anim 38: 286-296

Rowland M, Tozer TN (1995) Clinical Pharmacokinetics: Concepts and Applications. 3rd edn., Chapter 7, pp 83-105. Williams and Wilkins (now Lippincott, Williams and Wilkins): Philadelphia, USA

Rubio-Viqueira B, Hidalgo M (2009) Direct in vivo xenograft tumor model for predicting chemotherapeutic drug response in cancer patients. Clin Pharmacol Ther 85: 217-221

Rusciano D, Lorenzoni P, Burger M (1994) Murine models of liver metastasis. Invasion Metastasis 14: 349-361

Russell PJ, Ho Shon I, Boniface GR, Izard ME, Philips J, Raghavan D, Walker KZ (1991) Growth and metastasis of human bladder cancer xenografts in the bladder of nude rats. A model for intravesical radioimmunotherapy. Urol Res 19: 207-213

Russell WMS, Burch RL (1959) The Principles of Humane Experimental Technique. Methuen: London

Santarius T, Shipley J, Brewer D, Stratton MR, Cooper CS (2010) A census of amplified and overexpressed human cancer genes. Nat Rev Cancer 10: $59-64$

Sausville EA, Burger AM, Becher OJ, Holland EC (2006) Contributions of human tumor xenografts to anticancer drug development 10.1158/00085472.CAN-05-3627. Cancer Res 66: 3351-3354

Sawyers C (2004) Targeted cancer therapy. Nature 432: 294-297

Serganova I, Moroz E, Vider J, Gogiberidze G, Moroz M, Pillarsetty N, Doubrovin M, Minn A, Thaler HT, Massague J, Gelovani J, Blasberg R (2009) Multimodality imaging of TGFbeta signaling in breast cancer metastases. FASEB J 23: $2662-2672$

Sharkey RM, Weadock KS, Natale A, Haywood L, Aninipot R, Blumenthal RD, Goldenberg DM (1991) Successful radioimmunotherapy for lung metastasis of human colonic cancer in nude mice. J Natl Cancer Inst 83: 627-632

Sharpless NE, DePinho RA (2006) The mighty mouse: genetically engineered mouse models in cancer drug development. Nat Rev Drug Discov 5: $741-754$

Shibata H, Toyama K, Shioya H, Ito M, Hirota M, Hasegawa S, Matsumoto H, Takano H, Akiyama T, Toyoshima K, Kanamaru R, Kanegae Y, Saito I, Nakamura Y, Shiba K, Noda T (1997) Rapid colorectal adenoma formation initiated by conditional targeting of the Apc gene. Science 278: $120-123$

Shibata MA, Shibata E, Morimoto J, Eid NA, Tanaka Y, Watanabe M, Otsuki Y (2009) An immunocompetent murine model of metastatic mammary cancer accessible to bioluminescence imaging. Anticancer Res 29: $4389-4395$

Siim BG, Lee AE, Shalal-Zwain S, Pruijn FB, McKeage MJ, Wilson WR (2003) Marked potentiation of the antitumour activity of chemotherapeutic drugs by the antivascular agent 5,6-dimethylxanthenone-4-acetic acid (DMXAA). Cancer Chemother Pharmacol 51: 43-52

Singh SS (2006) Preclinical pharmacokinetics: an approach towards safer and efficacious drugs. Curr Drug Metab 7: 165-182

Sinn E, Muller W, Pattengale P, Tepler I, Wallace R, Leder P (1987) Coexpression of MMTV/v-Ha-ras and MMTV/c-myc genes in transgenic mice: synergistic action of oncogenes in vivo. Cell 49: 465-475

Smith NF, Raynaud FI, Workman P (2007) The application of cassette dosing for pharmacokinetic screening in small-molecule cancer drug discovery. Mol Cancer Ther 6: 428-440 
Soucek L, Whitfield J, Martins CP, Finch AJ, Murphy DJ, Sodir NM, Karnezis AN, Swigart LB, Nasi S, Evan GI (2008) Modelling Myc inhibition as a cancer therapy. Nature 455: 679-683

Spaeth EL, Dembinski JL, Sasser AK, Watson K, Klopp A, Hall B, Andreeff M, Marini F (2009) Mesenchymal stem cell transition to tumorassociated fibroblasts contributes to fibrovascular network expansion and tumor progression. PLoS One 4: e4992

Stambolic V, Tsao MS, Macpherson D, Suzuki A, Chapman WB, Mark TW (2000) High incidence of breast and endometrial neoplasia resembling human Cowden syndrome in pten $+/$ - mice. Cancer Res 60: 3605-3611

Stratton MR, Campbell PJ, Futreal PA (2009) The cancer genome. Nature 458: $719-724$

Sung H, Kang SH, Bae YJ, Hong JT, Chung YB, Lee CK, Song S (2006) PCRbased detection of mycoplasma species. J Microbiol 44: 42-49

Takeda N, Diksic M (1999) Relationship between drug delivery and the intra-arterial infusion rate of SarCNU in C6 rat brain tumor model. J Neurooncol 41: 235 - 246

Taketo MM (2006) Mouse models of gastrointestinal tumors. Cancer Sci 97: $355-361$

Tan M, Fang HB, Tian GL, Houghton PJ (2005) Repeated-measures models with constrained parameters for incomplete data in tumour xenograft experiments. Stat Med 24: 109-119

Tanaka T, Konno H, Matsuda I, Nakamura S, Baba S (1995) Prevention of hepatic metastasis of human colon cancer by angiogenesis inhibitor TNP-470. Cancer Res 55: 836-839

Tennant DA, Frezza C, MacKenzie ED, Nguyen QD, Zheng L, Selak MA, Roberts DL, Dive C, Watson DG, Aboagye EO, Gottlieb E (2009) Reactivating HIF prolyl hydroxylases under hypoxia results in metabolic catastrophe and cell death. Oncogene 28: 4009-4021

Tsai PP, Stelzer HD, Schraepler A, Hackbarth H (2006) Importance and effects of enrichment on physiology, behaviour and breeding performance in mice. Altex 23 (Suppl): 96-98

Tuchin VV (1993) Laser light scattering in biomedical diagnostics and therapy. J Laser Appl 5: 43-60

Ullman-Cullere MH, Foltz CJ (1999) Body condition scoring: a rapid and accurate method for assessing health status in mice. Lab Anim Sci 49: 319-323

van Furth WR, Laughlin S, Taylor MD, Salhia B, Mainprize T, Henkelman M, Cusimano MD, Ackerley C, Rutka JT (2003) Imaging of murine brain tumors using a 1.5 Tesla clinical MRI system. Can J Neurol Sci 30: 326-332 van Kranen HJ, de Gruijl FR (1999) Mutations in cancer genes of UV-induced skin tumors of hairless mice. J Epidemiol 9: S58-S65

Varticovski L, Hollingshead MG, Robles AI, Wu X, Cherry J, Munroe DJ, Lukes L, Anver MR, Carter JP, Borgel SD, Stotler H, Bonomi CA, Nunez NP, Hursting SD, Qiao W, Deng CX, Green JE, Hunter KW, Merlino G, Steeg PS, Wakefield LM, Barrett JC (2007) Accelerated preclinical testing using transplanted tumors from genetically engineered mouse breast cancer models. Clin Cancer Res 13: 2168-2177

Verheul HM, Hammers H, van Erp K, Wei Y, Sanni T, Salumbides B, Qian DZ, Yancopoulos GD, Pili R (2007) Vascular endothelial growth factor trap blocks tumor growth, metastasis formation, and vascular leakage in an orthotopic murine renal cell cancer model. Clin Cancer Res 13: $4201-4208$

Vogelstein B, Kinzler KW (2004) Cancer genes and the pathways they control. Nat Med 10: 789-799

Warden SJ, Bennell KL, McMeeken JM, Wark JD (2000) A technique for restraining rodents during hindlimb interventions. Contemp Top Lab Anim Sci 39: 24-27

Watanabe H, Uesaka T, Kido S, Ishimura Y, Shiraki K, Kuramoto K, Hirata S, Shoji S, Katoh O, Fujimoto N (1999) Gastric tumor induction by 1,2-dimethylhydrazine in Wistar rats with intestinal metaplasia caused by X-irradiation. Jpn J Cancer Res 90: 1207-1211

Watanabe T, Schulz D, Morisseau C, Hammock BD (2006) High-throughput pharmacokinetic method: cassette dosing in mice associated with minuscule serial bleedings and LC/MS/MS analysis. Anal Chim Acta 559: 37-44

Watson SA, Michaeli D, Morris TM, Clarke P, Varro A, Griffin N, Smith A, Justin T, Hardcastle JD (1999a) Antibodies raised by gastrimmune inhibit the spontaneous metastasis of a human colorectal tumour, AP5LV. Eur J Cancer 35: 1286-1291

Watson SA, Morris TM, Varro A, Michaeli D, Smith AM (1999b) A comparison of the therapeutic effectiveness of gastrin neutralisation in two human gastric cancer models: relation to endocrine and autocrine/ paracrine gastrin mediated growth. Gut 45: 812-817
Weiss WA, Aldape K, Mohapatra G, Feuerstein BG, Bishop JM (1997) Targeted expression of MYCN causes neuroblastoma in transgenic mice. EMBO J 16: $2985-2995$

Weissleder R, Pittet MJ (2008) Imaging in the era of molecular oncology. Nature 452: $580-589$

Wells DJ, Playle LC, Enser WE, Flecknell PA, Gardiner MA, Holland J, Howard BR, Hubrecht R, Humphreys KR, Jackson IJ, Lane N, Maconochie M, Mason G, Morton DB, Raymond R, Robinson V, Smith JA, Watt N (2006) Assessing the welfare of genetically altered mice. Lab Anim 40: 111-114

Wetmore C, Eberhart DE, Curran T (2001) Loss of p53 but not ARF accelerates medulloblastoma in mice heterozygous for patched. Cancer Res 61: 513-516

Winter SF, Hunter KW (2008) Mouse modifier genes in mammary tumorigenesis and metastasis. J Mammary Gland Biol Neoplasia 13: 337-342

Wood PJ, Stratford IJ, Sansom JM, Cattanach BM, Quinney RM, Adams GE (1992) The response of spontaneous and transplantable murine tumors to vasoactive agents measured by $31 \mathrm{P}$ magnetic resonance spectroscopy. Int J Radiat Oncol Biol Phys 22: 473-476

Workman P, Balmain A, Hickman JA, McNally NJ, Rohas AM, Mitchison NA, Pierrepoint CG, Raymond R, Rowlatt C, Stephens TC, Wallace J (1988) UKCCCR guidelines for the welfare of animals in experimental neoplasia. Br J Cancer 58: 109-113

Workman P, Aboagye EO, Chung YL, Griffiths JR, Hart R, Leach MO, Maxwell RJ, McSheehy PM, Price PM, Zweit J (2006) Minimally invasive pharmacokinetic and pharmacodynamic technologies in hypothesistesting clinical trials of innovative therapies. J Natl Cancer Inst 98: $580-598$

Workman P, de Bono J (2008) Targeted therapeutics for cancer treatment: major progress towards personalised molecular medicine. Curr Opin Pharmacol 8: 359-362

Workman P, Twentyman P, Balkwill F, Balmain A, Chaplin D, Double J, Embleton J, Newell D, Raymond R, Stables J, Stephens T, Wallace J (1998) UKCCCR guidelines for the welfare of animals in experimental neoplasia (Second Edition). Br J Cancer 77: 1-10

Xu X, Wagner KU, Larson D, Weaver Z, Li C, Ried T, Hennighausen L, Wynshaw-Boris A, Deng CX (1999) Conditional mutation of Brcal in mammary epithelial cells results in blunted ductal morphogenesis and tumour formation. Nat Genet 22: 37-43

Yang L, Mao H, Cao Z, Wang YA, Peng X, Wang X, Sajja HK, Wang L, Duan H, Ni C, Staley CA, Wood WC, Gao X, Nie S (2009) Molecular imaging of pancreatic cancer in an animal model using targeted multifunctional nanoparticles. Gastroenterology 136: 1514-1525; e2

Yang M, Reynoso J, Jiang P, Li L, Moossa AR, Hoffman RM (2004) Transgenic nude mouse with ubiquitous green fluorescent protein expression as a host for human tumors. Cancer Res 64: 8651-8656

Yang W, Velcich A, Mariadason J, Nicholas C, Corner G, Houston M, Edelmann W, Kucherlapati R, Holt PR, Augenlicht LH (2001) p21(WAF1/ cip1) is an important determinant of intestinal cell response to sulindac in vitro and in vivo. Cancer Res 61: 6297-6302

Yoshino K, Iimura E, Saijo K, Iwase S, Fukami K, Ohno T, Obata Y, Nakamura Y (2006) Essential role for gene profiling analysis in the authentication of human cell lines. Hum Cell 19: 43-48

Zavaleta CL, Goins BA, Bao A, McManus LM, McMahan CA, Phillips WT (2008) Imaging of 186Re-liposome therapy in ovarian cancer xenograft model of peritoneal carcinomatosis. J Drug Target 16: 626-637

Zhau HE, Li CL, Chung LW (2000) Establishment of human prostate carcinoma skeletal metastasis models. Cancer 88: 2995-3001

Zheng Q, Chen XY, Shi Y, Xiao SD (2004) Development of gastric adenocarcinoma in Mongolian gerbils after long-term infection with Helicobacter pylori. J Gastroenterol Hepatol 19: 1192-1198

Zhu JS, Song MQ, Chen GQ, Li Q, Sun Q, Zhang Q (2007) Molecular mechanisms of paclitaxel and NM-3 on human gastric cancer in a severe combined immune deficiency mice orthotopic implantation model. World J Gastroenterol 13: 4131-4135

Zisman A, Pantuck AJ, Bui MH, Said JW, Caliliw RR, Rao N, Shintaku P, Berger F, Gambhir SS, Belldegrun AS (2003) LABAZ1: a metastatic tumor model for renal cell carcinoma expressing the carbonic anhydrase type 9 tumor antigen. Cancer Res 63: 4952-4959

Zuber J, Radtke I, Pardee TS, Zhao Z, Rappaport AR, Luo W, McCurrach ME, Yang MM, Dolan ME, Kogan SC, Downing JR, Lowe SW (2009) Mouse models of human AML accurately predict chemotherapy response. Genes Dev 23: 877-889 


\section{Additional information}

Committee to Update Science, Medicine, and Animals, National Research Council (2004) Sciences, Medicine, and Animals: National Research Council of The National Academies. The National Academies Press: Washington, DC, USA

Dennis C (2006) Cancer: off by a whisker. Nature 17: 739-741

Garber K (2006) Realistic rodents? Debate grows over new mouse models of cancer. J Natl Cancer Inst 98: 1176-1178

Guidelines for the Care and Use of Mammals in Neuroscience and Behavioural Research. Committee on Guidelines for the Use of Animals in Neuroscience and Behavioural Research, (Institute for Laboratory Animal Research, Washington, D.C. 2003). National Research Council

Flecknell P (2008) Analgesia from a veterinary perspective. $\mathrm{Br} J$ Anaesth 101: 121-124

Richardson CA, Flecknell PA (2005) Anaesthesia and postoperative analgesia following experimental surgery in laboratory rodents: are we making progress? Altern Lab Anim 33: 119-127

Roughan JV, Flecknell PA, Davies BR (2004) Behavioural assessment of the effects of tumour growth in rats and the influence of the analgesics carprofen and meloxicam. Lab Anim 38: 286-296

The Royal Society (2004) The Use of Non-human Animals in Research: a Guide for Scientists. Science Advice Section, The Royal Society: London, UK

\section{Glossary}

Allometric scaling: Calculation of doses of drugs to be administered to animals according to their relative sizes where the relationship of a biological variable to body mass is non-linear. For example, drug dosage can be linearly related to body surface area rather than to body weight.

Ascites: Cells/fluid in the peritoneal cavity.

Autochthonous tumours: Tumours originating within the host animal, either spontaneously, or due to genetic or pharmacological intervention.

Cachexia: Severe loss of weight and muscle mass that cannot be reversed nutritionally. Can be caused by release of biologically active molecules (cytokines) from certain tumours.

Cassette dosing: Administration of multiple compounds to an individual animal followed by individual measurements in the same blood sample.

Clinically equivalent dose: A dose of a drug, which results in blood/tissue levels that reflect those that are achieved in patients.

Clonogenic assay: Measuring the effect of treatments on the ability of tumour cells to proliferate expansively. Treatment may be in vitro or initiated in vivo and the clonogenic ability of explanted cells tested in vitro.

Desquamation: Loss of skin integrity. Moist desquamation can be a consequence of exposure to ionising radiation (UV or X-rays) where the skin thins and then begins to weep tissue fluid as the epithelial cells lose their barrier function.

Distension: Stretched beyond normal dimensions.

Ectopic: Site of growth different from the tissue of origin, for example, s.c. transplantation of tumours derived from internal organs.

Erythema: Skin reddening and thickening in response to UV irradiation, as in mild sunburn.

Factorial design: Involves the inclusion of two or more variables and measuring the response to each variable and interactions between variables.

Genetically engineered mouse models (GEMMs): Animals in which the genetic material has been altered. For example, introduction of a mutation in cells of a particular organ may result in the development of benign or malignant tumours.

Hyperplasia: Refers to the proliferation of cells within an organ or tissue beyond that which is ordinarily seen. Microscopically

\section{Useful weblinks}

http://scienceandresearch.homeoffice.gov.uk/animal-research/ publications-and-reference/statistics/ http://www.sanger.ac.uk/genetics/CGP http://emice.nci.nih.gov/mouse_models http://dels.nas.edu/ilar_n/ilarhome/reports.shtml http://ec.europa.eu/environment/chemicals/lab animals/home en.htm http://www.iasp-pain.org/AM/Template.cfm?Section=Animal_Research http://ec.europa.eu/european_group_ethics/docs/opinion7_en.pdf $\mathrm{http} / / /$ conventions.coe.int/treaty/en/treaties/html/123.htm http://www.ecopa.eu/ http://caat.jhsph.edu/ http://www.imm.ki.se/sft/pdf/OECD19.pdf http://oacu.od.nih.gov/ARAC/index.htm http://www.research.psu.edu/arp/health/endpoints.html http://www.nc3rs.org.uk/news.asp?id=759 http://ddgs.utu.fi/request.php?4 http://www.lal.org.uk/index.php?option=com_content\&view=article\& id=56\&Itemid

http://www.nc3rs.org.uk

cells resemble normal cells but are increased in numbers. It is a benign condition, unlike neoplasia, which is malignant.

Intravital microscopy: A technique, which allows direct observation of small blood vessels within the organs of anesthetised animals.

Maximum Tolerated Dose (MTD): The highest dose of a drug in which the clinical condition of the experimental animal is maintained.

Metastasis: The spread of tumour cells from a primary site to distant sites in the body, usually through the blood or lymph. The term 'experimental metastasis' is sometimes used to describe the colonisation of organs after injection of cells directly into the peripheral circulation.

Oncogenesis: The process of malignant transformation resulting in tumour development.

Orthotopic: Anatomically correct site (opposite of ectopic), for example, transplantation of renal tumour cells into the kidney or mammary carcinoma cells into the mammary fat pad.

Pharmacodynamics: The study of the action of and the duration of effects of agents in the body, including confirmation of mechanism of action through identification of relevant biomarkers of activity.

Pharmacokinetics: The study of the process by which agents are absorbed, distributed, metabolized and eliminated by the body, including measurement of the rate of excretion, metabolism, blood and tissue concentrations.

Syngeneic tumour models: Cells transplanted between animals of the same inbred strain.

Ulceration: An inflamed lesion on the skin or internal surface involving tissue destruction.

Xenogeneic tumour models: Cells transplanted between species (e.g., human to mouse). Requires recipients that cannot mount an immune response and reject the foreign tissue graft such as athymic mice which lack T-lymphocytes, or severe combined immunodeficient (SCID) mice.

(c) (9) This work is licensed under the Creative Commons cc. BY NC SA Attribution-NonCommercial-Share Alike 3.0 License. To view a copy of this license, visit http://creativecommons.org/ licenses/by-nc-sa/3.0/ 